\title{
Are Large Herbivores Vectors of Terrestrial Subsidies for Riverine Food Webs?
}

\author{
Frank O. Masese, ${ }^{1 *}$ Kátya G. Abrantes, ${ }^{2}$ Gretchen M. Gettel, ${ }^{1}$ \\ Steven Bouillon, ${ }^{3}$ Kenneth Irvine, ${ }^{1}$ and Michael E. McClain ${ }^{1}$
}

\begin{abstract}
${ }^{1}$ Department of Water Science and Engineering, UNESCO-IHE Institute for Water Education, P.O Box 3015, 2601 DA Delft, The Netherlands; ${ }^{2}$ Estuary and Tidal Wetland Ecosystems Research Group, School of Marine and Tropical Biology, Centre for Tropical Water and Aquatic Ecosystem Research (TropWater), James Cook University, Townsville, Queensland 4811, Australia; ${ }^{3}$ Department of Earth and Environmental Sciences, Katholieke Universiteit Leuven (KU Leuven), Celestijnenlaan 200E, 3001 Leuven, Belgium
\end{abstract}

\begin{abstract}
The tropical savannas of Africa have witnessed a dramatic reduction in native large mammalian herbivore populations. The consequences of these changes for terrestrial-aquatic food-web linkages are poorly documented. We used natural abundances of stable carbon and nitrogen isotopes $\left(\delta^{13} \mathrm{C}\right.$, $\delta^{15} \mathrm{~N}$ ) to determine spatial and temporal patterns in the importance of herbivore-mediated subsidies for consumers in the Mara River, Kenya. Potential primary producers (terrestrial C 3 and C4 producers and periphyton) and consumers (invertebrates and fish) were collected during dry and wet seasons from different sites along the river, representing a gradient from forested highlands to natural savanna grasslands with high herbivore densities across mixed agricultural and livestock-dominated zones. Bayesian mixing models were used to estimate the relative contributions of terrestrial and algal sources of organic carbon supporting consumer trophic groups. Organic carbon sources differed for con-
\end{abstract}

Received 11 July 2014; accepted 23 January 2015

Electronic supplementary material: The online version of this article (doi:10.1007/s10021-015-9859-8) contains supplementary material, which is available to authorized users.

Author contributions FOM, lead author, conceived research, performed field sampling, performed sample and data analysis and wrote paper. KGA performed data analysis and wrote paper. GMG contributed to research design and wrote paper. SB performed sample analysis and wrote paper. KI contributed to research design and wrote paper. MEM conceived research, performed field sampling, and wrote paper.

*Corresponding author; e-mail: f.masese@gmail.com sumer groups and sites and with season. Overall, periphyton was the major energy source for most consumer groups during the dry season, but with wide $95 \%$ confidence intervals. During the wet season, the importance of terrestrial-derived carbon for consumers increased. The importance of $\mathrm{C} 3$ producers declined from 40 and $41 \%$ at the forested upper reaches to 20 and $8 \%$ at river reaches receiving hippo inputs during the dry and wet seasons, respectively. The reciprocal increase in the importance of $\mathrm{C} 4$ producers was higher than expected based on areal cover of riparian vegetation that was mainly $\mathrm{C} 3$. The importance of $\mathrm{C} 4$ producers notably increased from 18 and $10 \%$ at the forested upper reaches to 33 and $58 \%$ at river reaches receiving hippo inputs during the dry and wet seasons, respectively. This study highlights the importance of large herbivores to the functioning of riverine ecosystems and the potential implications of their loss from savanna landscapes that currently harbor remnant populations. Although the importance of $\mathrm{C} 4$ terrestrial carbon in most river systems has been reported to be negligible, this study shows that its importance can be mediated by large herbivores as vectors, which enhance energetic terrestrial-aquatic linkages in rivers in savanna landscapes.

Key words: trophic subsidies; allochthony; food webs; hippopotamus; C4 carbon sources; stable isotopes; SIAR models; tropical rivers. 


\section{INTRODUCTION}

The importance of different sources of organic carbon to riverine food webs has been postulated to vary longitudinally along the river continuum (Vannote and others 1980; Junk and others 1989; Thorp and Delong 1994). Transfers of terrestrial organic matter and nutrients can provide important subsidies to receiving aquatic ecosystems, enhancing primary and secondary production (Polis and others 1997; Paetzold and others 2007). In this regard, movement of large herbivores can be an active vector when they defecate or urinate in the water (Naiman and Rogers 1997). However, large populations of herbivorous mammals that were once key features of many landscapes have been decimated by human actions and replaced to some extent by domesticated cattle (Prins 2000; Wardle and others 2011). The effect of this loss on terrestrial-aquatic food-web linkages is largely unknown.

Trophic energy sources are dynamic in space and time depending on prevailing environmental conditions (de Ruiter and others 2005). For instance, flow variation in rivers influences ecosystem size, organic matter flux, light and nutrient availability for primary production (Tank and others 2010). Subsidy pathways can also change seasonally because of changes in connectivity, flowpaths, and vectors of transport (Paetzold and others 2007). For instance, during the dry season, terrestrial animals visit watering points more frequently (Bond and others 2012) and in savanna landscapes, many herbivores congregate near watering points (Ogutu and others 2010). The effects of transfers also depend on the quality of the subsidy relative to local resources. Algal carbon contributes significantly to aquatic animal biomass in mid-sized and large rivers despite forming a small proportion of available food resources; more abundant detritus from vascular plants contributes significantly less to aquatic animal biomass (Lewis and others 2001; Douglas and others 2005; Jardine and others 2012). Moreover, because of its poorer quality, C4 grasses are understood to contribute minimally to aquatic food webs compared with C3 vegetation (Roach 2013).

Stable isotope analysis (SIA) provides a time-integrated measure of carbon flow and trophic interactions (Fry and Sherr 1989). The ratio of ${ }^{13} \mathrm{C}$ to ${ }^{12} \mathrm{C}$ isotopes (expressed as $\delta^{13} \mathrm{C}$ values) is used to identify different organic carbon sources and to infer energy flow through food webs because of the small fractionation $(0-1 \%$ ) from food source to consumer (Fry and Sherr 1989; McCutchan and others 2003). Alternatively, the ratio of ${ }^{15} \mathrm{~N}$ to ${ }^{14} \mathrm{~N}$ isotopes (expressed as $\delta^{15} \mathrm{~N}$ values) is generally used to infer the trophic position of a consumer due to its higher trophic fractionation $(\sim 3 \%$, Post 2002; McCutchan and others 2003). The use of two or more isotopes strengthens the discrimination between potential food sources, especially in cases where sources overlap in one of the isotopes (Peterson and others 1985). In addition, the isotopic composition of potentially important aquatic primary producers such as periphyton can vary spatially and temporally (Finlay 2004). Therefore, sampling across seasons to capture potential variability in primary producer isotopic composition is important for estimating food web dynamics in aquatic ecosystems (O'Reilly and others 2002).

East African rivers display highly seasonal flow regimes with well-defined wet and dry seasons (McClain and others 2014), leading to annual cycles in habitat and nutrient availability and productivity (Marwick and others 2014a). The supply of terrestrial nutrients to aquatic food webs is spatially and seasonally variable, and is greatest in deforested and grazing areas during the wet season (Defersha and Melesse 2012; Dutton 2012). Animal-mediated subsidies are also dependent on animal behavior and population densities (Grey and Harper 2002; Jacobs and others 2007; Subalusky and others 2014). The Mara River (Kenya, Tanzania) traverses a landscape gradient that presents a unique case for studying the influence of both human and animal populations on terrestrial-aquatic food-web linkages. The upper reaches are forested but transition into mixed small- and large-scale agriculture and human settlements at the foot of the Mau Escarpment and into rangelands and protected areas in the lower-middle reaches.

The aim of this study is to investigate the energy sources fuelling river food webs in the Mara River, and the effects of large mammalian herbivores and hydrological seasonality on terrestrial subsidies. We hypothesize that the relative contributions of carbon sources to consumers differ between wet and dry seasons, and that terrestrial producers are more important in river reaches influenced by large herbivores and during the wet season when runoff transports organic matter and nutrients of terrestrial origin from the catchment and reduces the availability of algal sources via scouring and sedimentation. To address these hypotheses, we sampled regions with different surrounding vegetation (C3 vs. C4) and herbivore densities and used $\delta^{13} \mathrm{C}$ and $\delta^{15} \mathrm{~N}$ to identify the main sources of energy supporting consumers in the different reaches of the river. 


\section{Materials and Methods}

\section{Study Area}

The study was conducted on the Kenyan sections of the Mara River, before crossing into Tanzania and discharging into Lake Victoria. The Mara River drains a number of forest blocks that are part of the Mau Forest Complex (MFC), the most extensive tropical moist broadleaf forest in East Africa (Jackson and McCarter 1994). Two perennial tributary rivers, the Nyangores and Amala, drain the forested headwaters before joining to form the Mara mainstem (Figure 1). Tributaries draining the grasslands and shrublands of the middle and lower basin are ephemeral. Only the Talek River joins the Mara River before it crosses into Tanzania. Until the middle of the past century, the $13,500 \mathrm{~km}^{2}$ Mara River basin was covered by montane forest in its headwaters and a mixture of shrublands and grasslands throughout its middle and lower reaches. However, agricultural expansion over the basin has been on the increase, accounting for approximately $1500 \mathrm{~km}^{2}$ of the basin in 1973 and nearly $4500 \mathrm{~km}^{2}$ by the year 2000 (Mati and others 2008).

On the highlands, climate is relatively cool and seasonal, characterized by distinct rainfall seasons and low ambient temperatures that fall below $10^{\circ} \mathrm{C}$ during January-February. The highlands receive around $2000 \mathrm{~mm}$ of rainfall per annum, whereas the lowlands receive around $1000 \mathrm{~mm}$. Dry conditions are experienced during December-March

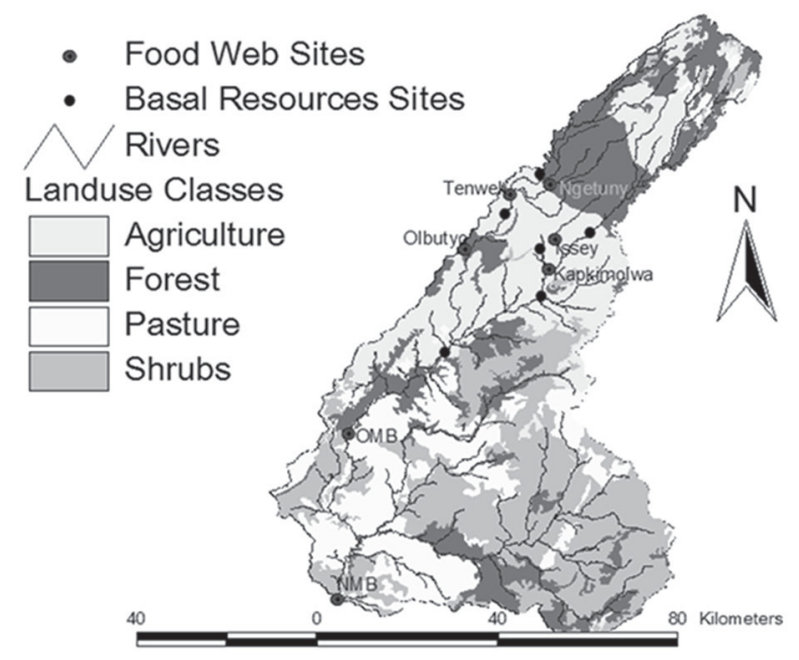

Figure 1. Map of the study are showing the position of the study sites. The main food web sampling sites are named whereas the basal resources sites are indicated with small black circles. The OMB and NMB were combined into Mara Main site for food web analysis. and August-September, whereas two wet seasons occur during March-May and October-December (Jackson and McCarter 1994).

The basin hosts substantial numbers of livestock but densities vary throughout the catchment. The upper reaches are under crop farming and husbandry of small herds of cattle. The middle reach rangelands of the Maasai contain large herds, with over 220,000 cattle estimated to graze within the middle Mara and Talek regions (Lamprey and Reid 2004; Ogutu and others 2011). The savanna grasslands in the Masai Mara National Reserve (MMNR) and Serengeti National Park (SNP) harbor more than a million residents and migratory ungulates (Lamprey and Reid 2004), including 4000 hippos (Hippopotamus amphibius) that graze on terrestrial grasses at night and defecate into the river during the day (Kanga and others 2011).

\section{Sampling Protocols}

Sites for food web studies were selected based on land use and riparian influences by people, livestock, and hippos along the river (Table 1). A total of seven sites were sampled for food web analysis. Four sites were sampled weekly for eight weeks during the dry (February-March 2012) and wet (May-July 2011) seasons to account for the temporal variation in isotopic composition of basal sources (Table 2): one site (Ngetuny) was located upstream in the forest zone where $\mathrm{C} 3$ vegetation dominates the catchment and human and animal activities are minimal; three sites (Tenwek, Issey and Kapkimolwa) were located in more downstream areas influenced by agriculture (mainly maize and tea plantations and livestock pastures) to different degrees. Three additional sites were sampled only once during the dry season (March 2012) and once during the wet season (July 2011): the Olbutyo site, influenced by agriculture (mainly maize, beans, potatoes, and livestock pastures) and two sites (OMB and NMB, combined and referred to hereafter as the Mara Main site) located on the Mara mainstem within the MMNR, in river sections inhabited by large populations of hippos (Kanga and others 2011). In addition to the seven primary food web sites, six more sites were sampled once during the dry and wet seasons to provide additional data and spatial coverage for characterizing basal energy resources. During sampling, discharge in the Mara River before its confluence with the Talek River averaged around $5 \mathrm{~m}^{3} / \mathrm{s}$ during the wet season May-July 2011 and around $3.5 \mathrm{~m}^{3} / \mathrm{s}$ during the dry season January-April 2012. These levels are lower than the long-term averages (Supplementary Figure S1). 
Table 1. Characteristics of the Sampling Sites Used for Food Web Studies in the Mara River Basin, Kenya

\begin{tabular}{|c|c|c|c|c|c|c|c|}
\hline $\begin{array}{l}\text { Sampling } \\
\text { site }\end{array}$ & Land use influences & $\begin{array}{l}\text { RDIS } \\
\left(\mathrm{km}^{2}\right)\end{array}$ & $\begin{array}{l}\text { Elevation } \\
\mathrm{m} \text { asl }\end{array}$ & $\begin{array}{l}\% \text { Agriculture } \\
\text { (cultivated } \\
\text { land) }\end{array}$ & $\begin{array}{l}\% \text { Grasslands } \\
\text { and grazing } \\
\text { land (C4) }\end{array}$ & $\begin{array}{l}\text { \% Forest } \\
\text { (C3) }\end{array}$ & $\begin{array}{l}\text { Herbivore } \\
\text { density } \\
\text { (individuals/ } \\
\mathrm{km}^{2} \text { ) }\end{array}$ \\
\hline Ngetuny & Forest & 12.3 & 2063 & 21.7 & 0.9 & 77 & 5 \\
\hline Issey & Agriculture & 8.0 & 1980 & 37.5 & 3.9 & 58.6 & 35 \\
\hline Kapkimolwa & Agriculture & 26.4 & 1854 & 41.8 & 16.4 & 41.8 & 60 \\
\hline Tenwek & Agriculture & 25.7 & 1937 & 34.4 & 3.1 & 62.5 & 24 \\
\hline Olbutyo & Agriculture & 28.0 & 1857 & 38.3 & 6.6 & 55.1 & 44 \\
\hline OMB & $\begin{array}{l}\text { Hippos, ungulates, } \\
\text { and C4 grasslands }\end{array}$ & 54.6 & 1580 & 49.4 & 15.0 & 35.6 & 98 \\
\hline NMB & $\begin{array}{l}\text { Hippos, ungulates, } \\
\text { and C4 grasslands }\end{array}$ & 80.7 & 1475 & 23.2 & 53.4 & 23.4 & 104 \\
\hline
\end{tabular}

Land use influences capture the main land use activities in the adjoining areas of the sites whereas \% agriculture, grasslands, and forest represent the estimated areal coverage in the catchments. River distance (RDIS) is calculated as the square root of drainage area upstream of the sampling site. Also presented is the density of herbivores (livestock and wildlife) within a kilometer square of each sampling site.

Measurements of $\mathrm{pH}$, dissolved oxygen (DO), temperature, and electrical conductivity were done in situ using a YSI multi-probe water quality meter (556 MPS, Yellow Springs Instruments, Ohio, USA). Water samples were collected from the thalweg using acid-washed HDP bottles for analysis of nutrients, dissolved organic carbon (DOC), and particulate organic matter (POM). For total suspended solids (TSS) and POM, stream water samples were immediately filtered through pre-weighed glass fiber filters (Whatman GF/F, pre-combusted at $450^{\circ} \mathrm{C}, 4 \mathrm{~h}$ ). GF/F filters holding suspended matter were wrapped in aluminum foil and stored in a cooler box at $4^{\circ} \mathrm{C}$. For water column chlorophyll $a$ ( $\mathrm{chl} a$ ) concentrations, a measured volume of water was filtered through a $0.7-\mu \mathrm{m}$ pore-sized glass fiber filter, which was then wrapped in aluminum foil to prevent exposure to light and transported in a cooler to the laboratory. Samples transported in cooler boxes to the laboratory were frozen within $10 \mathrm{~h}$ of sampling prior to analysis.

Samples for stable isotope analyses were collected during both the wet (May-July 2011) and dry (January-April 2012) seasons. At each site, samples of the dominant riparian vegetation and emergent and submerged macrophytes were collected by hand. Replicate benthic samples of coarse particulate organic matter (CPOM) were collected from pools, runs, and riffles using a dip net (500 $\mu \mathrm{m}$ mesh-size). Net contents were washed with site water to remove invertebrates and inorganic materials. Samples were immediately placed in polyethylene bags in cooler boxes for transport to the laboratory where they were frozen until further analysis. Fine benthic organic matter
(FBOM) was collected by disturbing an area of streambed by hand and filling 500-ml high-density polyethylene (HDPE) bottles with the mixture. Filamentous algae and lichens were collected by hand using a scalpel. Lichens were considered in this study because they were widespread and covered large surfaces of submerged stones in riffles and runs. Submerged surfaces containing lichens were thoroughly washed with site water to remove sediments and invertebrates before samples were collected. Because water velocity and elevation influence $\mathrm{CO} 2$ evasion to the atmosphere, and hence the spatial (including longitudinal) changes in $\delta^{13} \mathrm{C}$ of primary producers in rivers (Finlay 2001, 2004), efforts were made to sample only riffles and runs for periphyton at all sites. Periphyton were scrubbed with a toothbrush from submerged surfaces (mainly slippery rocks) in riffles and runs after washing gently with site water to remove any attached invertebrates, inorganic materials, and detritus. After decanting, the top fraction was separated and stored in 30-ml HDPE bottles, and then transported to the laboratory in cooler boxes for further processing. Seston was collected by placing a $30-\mu \mathrm{m}$ plankton net in riffles or runs at each site. After decanting and removing CPOM and other visible large fractions of material, the sample was stored in 30-ml HDPE bottles and placed in cooler boxes for transport to the laboratory.

Invertebrates were collected from riffles, runs, pools, and vegetated littoral areas at each site using a dip net ( $500 \mu \mathrm{m}$ mesh size). Aquatic primary producers and macroinvertebrates were collected more frequently within 8 weeks to better characterize the isotopic composition of lower trophic 


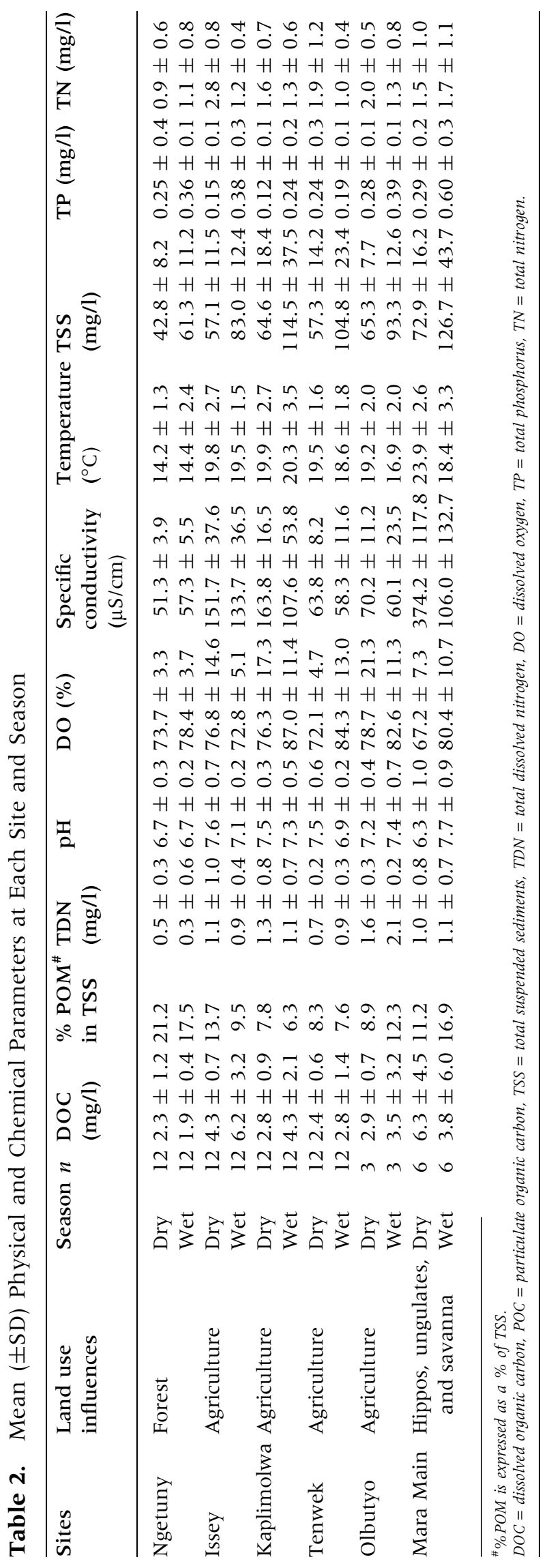

levels. To accommodate logistical and resource constraints, fish were collected toward the end of low- and high-flow periods. Fish were electroshocked from riffles, runs, pools, and littoral habitats, and individuals were measured and weighed in the field. Fish tissue was extracted from the white dorsal muscle in the field, as this is less variable in $\delta^{13} \mathrm{C}$ and $\delta^{15} \mathrm{~N}$ than other tissue types (Pinnegar and Polunin 1999). SIA samples were wrapped in aluminum foil and stored on ice in cooler boxes for transport to the laboratory where they were frozen until further analysis.

\section{Sample Preparation and Analysis}

Water quality variables determined in the laboratory included total suspended solids (TSS), particulate organic matter (POM), dissolved organic carbon (DOC), total dissolved nitrogen (TDN), total phosphorus (TP), total nitrogen (TN), and water column chla. GF/F filters holding suspended matter were dried $\left(95^{\circ} \mathrm{C}\right)$ to constant weight, and TSS was determined by re-weighing using an analytical balance and subtracting the filter weight. The filters were then ashed at $500^{\circ} \mathrm{C}$ for $4 \mathrm{~h}$ and re-weighed for the determination of POM as the difference between TSS and ash-free-dry weight. DOC and TDN concentrations were determined using a Shimadzu TOC-V-CPN with a coupled total nitrogen analyzer unit (TNM-1). TP and TN were determined using standard colorimetric methods (APHA 1998). Chla pigments were extracted by $90 \%$ ethanol in a hot water bath, and concentrations were determined spectrophotometrically.

In the laboratory, organic samples were prepared for SIA or stored in a $-20^{\circ} \mathrm{C}$ freezer for later processing. Coarse particulate organic matter samples were thoroughly washed with de-ionized water to remove inorganic materials and organisms. FBOM and seston were examined under a microscope to remove any living organisms. To clean periphyton, the slurry was centrifuged to decant heavier organic (detritus) and inorganic fractions and allow lighter periphyton to float. The periphyton was then decanted onto a Petri dish, and excess water evaporated in an oven at $60^{\circ} \mathrm{C}$ for $48 \mathrm{~h}$. The dry sample was then ground using a mortar and pestle, weighed, and packed in tin cups for SIA.

Before being frozen, invertebrates were kept in polyethylene bags filled with river water for at least $12 \mathrm{~h}$ to evacuate their guts. For confirmation, animals were then examined under a dissecting microscope to remove guts and contents. In most cases, individuals of a given taxon from each site were pooled to produce sufficient dry tissue to meet 
the required dry weight for SIA, except for crabs (Potamoutidae:Potamonautes spp.) and odonates, which were sufficiently large. For crabs and molluscs, only muscle tissue was used. Individual fish were analyzed separately. Prior to drying, muscle samples were rinsed in distilled water. All samples were oven-dried at $60^{\circ} \mathrm{C}$ for $48 \mathrm{~h}$. Samples were then ground and weighed into tin cups before SIA.

Stable isotope analyses were performed using continuous flow EA-IRMS (elemental analyserisotope ratio mass spectrometry). Samples were analyzed on either a ThermoFinnigan DeltaPlus stable isotope mass spectrometer (Thermo Scientific) coupled to a Costech ECS 4010 EA elemental analyzer (Costech Analytical Technologies) at the Yale Earth System Center for Stable Isotopic Studies (ESCSIS, Yale University, CT) or on a Thermo DeltaV Advantage coupled to a Carlo Erba EA1110 at the Katholieke Universiteit Leuven (KU Leuven, Belgium). Stable isotope ratios $\left({ }^{13} \mathrm{C} /{ }^{12} \mathrm{C}\right.$ and $\left.{ }^{15} \mathrm{~N} /{ }^{14} \mathrm{~N}\right)$ are expressed as parts per thousand $(\%$ oo deviations from standard, as defined by the equation: $\delta^{13} \mathrm{C}, \quad \delta^{15} \mathrm{~N}=\left[\left(R_{\text {sample }} / R_{\text {reference }}\right)-1\right] \times 10^{3}$, where $R={ }^{13} \mathrm{C} /{ }^{12} \mathrm{C}$ for carbon and ${ }^{15} \mathrm{~N} /{ }^{14} \mathrm{~N}$ for nitrogen. The global standard for $\delta^{13} \mathrm{C}$ is $\mathrm{V}-\mathrm{PDB}$ and for $\delta^{15} \mathrm{~N}$ is atmospheric nitrogen. Each run included an internal standard interspersed within samples to provide an estimate of instrument error. For samples analyzed at ESCSIS, the internal standard for animals was trout (Salvelinus fontinalis) muscle tissue $\left(\delta^{13} \mathrm{C}=-29.0 \% ; \quad \delta^{15} \mathrm{~N}=15.7 \% ; \quad 12.2 \% \quad \mathrm{~N}\right.$, $49.2 \% \mathrm{C}$ ) and for plants it was cocoa (Theobroma cacao $)\left(\delta^{13} \mathrm{C}=-28.7 \%, \delta^{15} \mathrm{~N}=5.1 \% ; 4.0 \% \mathrm{~N}\right.$, $47.9 \% \mathrm{C})$. The standard deviations of replicate samples of trout analyzed at ESCSIS were $0.29 \%$ for $\delta^{13} \mathrm{C}$ and $0.09 \%$ for $\delta^{15} \mathrm{~N}$, and for cocoa they were $0.27 \%$ for $\delta^{13} \mathrm{C}$ and $0.10 \%$ for $\delta^{15} \mathrm{~N}$. For KU Leuven samples, Acetanilide and Leucine were used as internal standards for $\delta^{13} \mathrm{C}$ (two points, with blank correction) and $\delta^{15} \mathrm{~N}$ calibration. $\mathrm{C}$ and $\mathrm{N}$ contents were assessed from the TCD signal of the EA, using acetanilide $(71.09 \% \mathrm{C}, 10.36 \% \mathrm{~N})$ as a standard. Replicate samples for internal standards had standard deviations of $<0.3 \%$ for $\delta^{13} \mathrm{C}$ and $\leq 0.2 \%$ for $\delta^{15} \mathrm{~N}$ during runs. Outputs from the two labs were compared by running 17 fish tissue samples in both. No systematic differences were obtained (paired 2-sample $t$ test, $t_{32}=0.02$, $P=0.983$ for $\delta^{13} \mathrm{C}$ and $t_{32}=1.05, P=0.309$ for $\delta^{15} \mathrm{~N}$ ) and, therefore, the results from the two labs were combined.

For fish with molar $\mathrm{C}: \mathrm{N}$ ratios above $3.5, \delta^{13} \mathrm{C}$ values were corrected for lipid content based on $\mathrm{C}: \mathrm{N}$ ratios using the equation recommended by
Post and others (2007), whereby corrected $\delta^{13} \mathrm{C}=\delta^{13} \mathrm{C}-3.32+0.99 \times \mathrm{C}: \mathrm{N}$. Invertebrate $\delta^{13} \mathrm{C}$ values were not corrected for lipid content because the shifts in $\delta^{13} \mathrm{C}$ associated with lipid removal can be very variable and taxon specific (Logan and others 2008).

\section{Trophic Guilds}

Classifications of fish trophic guilds were based on the literature (Corbet 1961; Raburu and Masese 2012) and stomach content data (not shown). Barbus altinialis, B. cercops, B. paludinosus, B. kerstenii, $B$. neumayeri, and Clarias liocephalus were considered representative of the insectivore guild; Labeo victorianus and Clarias gariepinus represented the omnivore guild; Chiloglanis sp. and Bagrus dokmac represented the piscivore guild. Macroinvertebrate trophic groups and functional feeding groups (FFGs) were based on Masese and others (2014) and references therein.

\section{Data Analysis}

For each site, river distance (RDIS) was calculated as the square root of drainage area. The length of stream paths of tributaries leading to a point in the drainage has been estimated to be a power function of the drainage area (DA ${ }^{0.5}$, Smart 1972). RDIS was used in this study as the independent variable against which longitudinal changes in isotopic values of basal sources were tested using simple linear regression (SLR); relationships were tested separately for dry and wet seasons. The influence of large herbivores (mainly livestock and hippos) on basal resources in the river was tested by SLR between the population density of large herbivores per sampling site and the stable isotopic composition of seston and FBOM. Herbivore (livestock, hippos, and herbivorous wildlife) density was expressed as number of individuals $/ \mathrm{km}^{2}$ in all the area above the sampling point or per river kilometer for the hippos. Data for livestock (cattle, sheep, goats, and donkeys) and wildlife (ungulates and hippos) were obtained from secondary sources that included District Development Plans for Bomet and Narok Districts (DDP 2008a, b), Ministry of Agriculture and Livestock Production reports (MALP 2009a, b), and other unpublished reports and publications (Lamprey and Reid 2004; KNBSIHBS 2007; KNBS-LS 2009; Kanga and others 2011; Ogutu and others 2011; Kiambi and others 2012) and were expressed as number of individuals per river kilometer. Using SLR, the relationship between large herbivore densities and the stable 
isotopic composition of seston and FBOM was investigated, because these herbivores are potential vectors of transport of C4 carbon (as feces) into the waterways. Stepwise multiple regressions were performed to partition the influence of herbivore densities, river distance, and \% C4 vegetation (grasslands and grazing lands) in the catchments on $\delta^{13} \mathrm{C}$ of seston, fine benthic organic matter, coarse particulate organic matter, filamentous algae, and periphyton separately for the dry and wet seasons.

The contributions of different basal sources to consumer diets were estimated with Bayesian mixing models using SIAR (Parnell and others 2010; R Project for Statistical Computing, Vienna, Austria). As opposed to other commonly used mixing models such as IsoSource (Phillips and Gregg 2003), SIAR accounts for variability and uncertainties associated with natural systems to give reliable estimates of the dietary composition of consumers (Parnell and others 2010). The SIAR model considers available sources and produces a range of feasible solutions that take into account uncertainty and variation in consumer and trophic enrichment factors (TEF). The model also provides error terms (the residual error) that give information on the variability that cannot be explained based on diet alone (Parnell and others 2010). Models were run for each site and season separately for the different trophic guilds (for invertebrates) and/ or individual taxa (for fish). C3 and C4 producers, periphyton, and lichens were included in the models as possible sources of energy, but due to overlaps in isotopic composition between periphyton and lichens at some sites containing both (Kapkimolwa and Ngetuny), samples were combined. Macrophytes were not included because they occurred in very low and patchy densities at the sampled river reaches and, hence, were assumed to contribute very little to food webs. For periphyton, $\delta^{13} \mathrm{C}$ and $\delta^{15} \mathrm{~N}$ of each site/season were used in the models to eliminate possible sources of error arising from spatio-temporal variability in isotopic composition (Finlay 2004). For C3 and C4 vegetation, however, the average $\delta^{13} \mathrm{C}$ and $\delta^{15} \mathrm{~N}$ from all sites and seasons was used in the models, as terrestrial organic matter (OM) from the overall catchment is transported into the system. Note, however, that the $\delta^{13} \mathrm{C}$ values of C3 and C4 producers did not differ among sites and seasons (data not shown).

For $\delta^{13} \mathrm{C}$, the trophic enrichment factor (TEF) used was $0.5 \%$ (McCutchan and others 2003), and a large $\delta^{13} \mathrm{C}$ TEF SD of $1.3 \%$ was set to account for the uncertainty in this fractionation value (for example, Post 2002). These TEFs were used taking into account the different trophic levels. For $\delta^{15} \mathrm{~N}$, we used TEFs in relation to the first trophic level of
$0.6 \pm 1.7 \%$ ( \pm TEF SD) for herbivorous invertebrates, $1.8 \pm 1.7 \%$ for predatory invertebrates, $4.3 \pm 1.5 \%$ for omnivorous fish, and $5.7 \pm 1.6 \%$ for predatory fish (Bunn and others 2013). Concentration dependencies were set to zero. When only one sample was available, the SIARSOLO command was used (Parnell and others 2010). SLR models were used to explore relationships between the estimated proportion of $\mathrm{C} 4$ vegetation cover in the catchments (expressed in \%) and the importance of C4 and of C3 producers to the different consumer groups.

\section{RESULTS}

\section{Physical and Chemical Variables}

There were both seasonal and spatial variabilities in water physical and chemical variables (Table 2). At all sites, except the Mara Main (which had hippos) and in the forest Ngetuny site, mean DOC concentrations were higher during the wet than during the dry season. Similarly, at most sites mean TDN, TSS, and TP concentrations were higher during the wet season compared with the dry season, whereas mean TN, conductivity, and temperature values were lower during the wet season (Table 2). At the agricultureinfluenced sites (Tenwek, Issey and Kapkimolwa), mean \% POM decreased during the wet season indicating input of sediments poor in organic matter. Mean chla concentration was lowest at the forested Ngetuny $(3.2 \pm 1.1 \mu \mathrm{g} / \mathrm{l})$ and highest at the Olbutyo site $(34.3 \pm 9.2 \mu \mathrm{g} / \mathrm{l})$. Dry season mgPOC: mgchl $a$ values ranged from $169 \pm 33$ at Olbutyo to $2836 \pm 412$ at the Ngetuny site. Overall, agricultural sites recorded higher mean temperature, specific conductivity, suspended sediments, and concentrations of nutrients and chla than the forest Ngetuny site (Table 2).

\section{Stable Isotope Values of Basal Sources}

For all sites, the $\delta^{13} \mathrm{C}$ values of the main producer categories were generally well separated (Table 3 ). However, although the $\delta^{13} \mathrm{C}$ values of $\mathrm{C} 3$ and $\mathrm{C} 4$ producers did not differ among sites and seasons (data not shown), mean $\delta^{13} \mathrm{C}$ of periphyton was lower during the wet season as compared with the dry season at some sites (Table 3). Longitudinally, mean periphyton $\delta^{13} \mathrm{C}$ values were lowest at the forest Ngetuny site $(-25.8 \pm 1.8 \%$ in the dry and $-26.9 \pm 1.1 \%$ in the wet season) and highest at the Mara Main site $(-17.3 \pm 0.9 \%$ in the dry and $-20.0 \pm 0.7 \%$ in the wet season). The mean $\delta^{15} \mathrm{~N}$ values of $\mathrm{C} 4$ producers were generally higher than those of C3 producers (Table 3). For periphyton, $\delta^{15} \mathrm{~N}$ values ranged from $6.3 \%$ at Olbutyo to greater than $9 \%$ at Issey. 
Table 3. $\delta^{13} \mathrm{C}$ and $\delta^{15} \mathrm{~N}$ (mean $\pm \mathrm{SD}$; in \%o of the Main Producer Categories Collected at Different Sites and in the Surrounding Catchment in the Dry and Wet Seasons

\begin{tabular}{|c|c|c|c|c|c|c|c|c|}
\hline \multirow[t]{2}{*}{ Site } & \multirow[t]{2}{*}{ Land use influences } & \multirow[t]{2}{*}{ Producers } & \multicolumn{3}{|c|}{ Dry } & \multicolumn{3}{|c|}{ Wet } \\
\hline & & & $n$ & $\delta^{13} \mathrm{C}$ & $\delta^{15} \mathrm{~N}$ & $n$ & $\delta^{13} \mathrm{C}$ & $\delta^{15} \mathrm{~N}$ \\
\hline \multirow[t]{2}{*}{ All sites } & & $C 3^{¥}$ & 61 & $-28.5 \pm 1.5$ & $4.1 \pm 2.8$ & 61 & $-28.5 \pm 1.5$ & $4.1 \pm 2.8$ \\
\hline & & $\mathrm{C} 4^{¥}$ & 8 & $-12.9 \pm 0.6$ & $8.4 \pm 2.9$ & 8 & $-12.9 \pm 0.6$ & $8.4 \pm 2.9$ \\
\hline \multirow[t]{3}{*}{ Ngetuny } & Forest & $\mathrm{C} 3$ & 1 & -28.0 & 3.0 & & $\mathrm{NC}$ & $\mathrm{NC}$ \\
\hline & & $\mathrm{C} 4$ & & NA & NA & & NA & NA \\
\hline & & Periphyton & 11 & $-25.8 \pm 1.8$ & $6.8 \pm 0.5$ & 13 & $-26.9 \pm 1.1$ & $6.5 \pm 1.1$ \\
\hline \multirow[t]{3}{*}{ Issey } & Agriculture & $\mathrm{C} 3$ & & $\mathrm{NC}$ & $\mathrm{NC}$ & 21 & $-28.4 \pm 1.7$ & $5.5 \pm 3.7$ \\
\hline & & $\mathrm{C} 4$ & & $\mathrm{NC}$ & $\mathrm{NC}$ & 2 & $-13.4 \pm 0.5$ & $13.1 \pm 1.4$ \\
\hline & & Periphyton & 8 & $-22.9 \pm 1.0$ & $9.1 \pm 0.8$ & 18 & $-23.1 \pm 2.0$ & $9.2 \pm 1.6$ \\
\hline \multirow[t]{3}{*}{ Kapkimolwa } & Agriculture & $\mathrm{C} 3$ & & $\mathrm{NC}$ & $\mathrm{NC}$ & 12 & $-28.3 \pm 1.3$ & $4.3 \pm 3.5$ \\
\hline & & $\mathrm{C} 4$ & & NA & NA & & NA & NA \\
\hline & & Periphyton + Lichens & 15 & $-19.6 \pm 2.6$ & $8.4 \pm 0.5$ & 18 & $-22.6 \pm 1.7$ & $7.5 \pm 0.8$ \\
\hline \multirow[t]{4}{*}{ Tenwek } & Agriculture & $\mathrm{C} 3$ & 9 & $-28.4 \pm 1.3$ & $6.9 \pm 5.7$ & & $\mathrm{NC}$ & $\mathrm{NC}$ \\
\hline & & $\mathrm{C} 4$ & 1 & -12.7 & 8.3 & & $\mathrm{NC}$ & $\mathrm{NC}$ \\
\hline & & Periphyton & 14 & $-20.2 \pm 2.3$ & $8.0 \pm 0.7$ & 15 & $-22.3 \pm 2.3$ & $7.3 \pm 0.6$ \\
\hline & & Lichens & 3 & $-23.4 \pm 0.7$ & $6.6 \pm 0.4$ & & $\mathrm{NC}$ & $\mathrm{NC}$ \\
\hline \multirow[t]{3}{*}{ Olbutyo } & Agriculture & C3 & 5 & $-29.7 \pm 1.3$ & $5.3 \pm 3.7$ & 5 & $-28.0 \pm 0.6$ & $4.2 \pm 2.0$ \\
\hline & & $\mathrm{C} 4$ & 1 & $-13,0$ & 8.7 & & $\mathrm{NC}$ & $\mathrm{NC}$ \\
\hline & & Periphyton & 2 & $-20.6 \pm 0.2$ & $6.3 \pm 0.1$ & 2 & $-26.1 \pm 1.3$ & $6.3 \pm 0.4$ \\
\hline \multirow[t]{3}{*}{ Mara main } & Hippos \& savanna & $\mathrm{C} 3$ & 8 & $-27.9 \pm 2.4$ & $4.8 \pm 2.3$ & & $\mathrm{NC}$ & $\mathrm{NC}$ \\
\hline & grasslands & $\mathrm{C} 4$ & 4 & $-13.3 \pm 1.3$ & $6.1 \pm 1.1$ & & $\mathrm{NC}$ & $\mathrm{NC}$ \\
\hline & & Periphyton & 6 & $-17.3 \pm 0.9$ & $6.4 \pm 1.2$ & 2 & $-20.0 \pm 0.7$ & $6.4 \pm 0.1$ \\
\hline
\end{tabular}

$N A=$ not available $N C=$ not collected $n=$ number of samples.

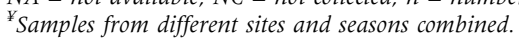

There were longitudinal increases in $\delta^{13} \mathrm{C}$ of seston, periphyton, CPOM, FBOM, and lichens in the Mara River during both the dry and wet seasons, but not for filamentous algae (Figure 2). For Issey and Kapkmolwa agricultural sites, $\delta^{13} \mathrm{C}$ was higher during the dry season. CPOM had higher $\delta^{13} \mathrm{C}$ values at the hippo and grassland Mara Main site during both the dry and wet seasons (OMB: mean $\pm \mathrm{SD},-17.5 \pm 0.8 \%$ during the dry season, $-15.5 \pm 0.8 \%$ during the wet season; and NMB: $-16.3 \pm 0.5 \%$ during the dry season; $-18.5 \pm$ $1.0 \%$ during the wet season; Figure 2).

Results of stepwise multiple regression analyses showed that the number of herbivores was the main predictor of $\delta^{13} \mathrm{C}$ of basal resources in the Mara River by displaying a significant influence on seston, FBOM, and periphyton during the dry and wet seasons (Table 4). The proportion of C4 vegetation in the catchment (\% C4 cover) was also an important predictor of $\delta^{13} \mathrm{C}$ of seston and CPOM during the dry season and FBOM during the wet season. River distance (RDS) displayed only a marginal influence on the $\delta^{13} \mathrm{C}$ of filamentous algae and periphyton during the dry season, but a significant one on CPOM during the wet season.
Longitudinal changes in $\delta^{15} \mathrm{~N}$ in the river did not follow $\delta^{13} \mathrm{C}$ patterns for most sources (Figure 3). However, $\delta^{15} \mathrm{~N}$ values of FBOM, periphyton, filamentous algae, and lichens were higher at agricultural sites. Seston and CPOM displayed significant longitudinal variability during the dry season (seston also during the wet season) with $\delta^{15} \mathrm{~N}$ decreasing with river distance from source (Figure 3). Agricultural sites had higher seston and CPOM $\delta^{15} \mathrm{~N}$ values, with low values in the forest (Ngetuny) and savanna grasslands (Mara Main) sites (Figure 3 ). The \% of agricultural land use was a strong predictor $\left(R^{2}=0.65, P<0.05\right)$ of $\delta^{15} \mathrm{~N}$ values of FBOM in the study area during the dry season.

Both herbivore density and the estimated \% of C4 vegetation cover in catchments had significant relationships with $\delta^{13} \mathrm{C}$ values of seston and of FBOM (Figure 4). The relationships were significant during both the dry and wet seasons, and $\delta^{13} \mathrm{C}$ values were higher at agricultural sites during the dry season (Figure 4). The \% of forest land use displayed a significant negative relationship with the $\delta^{13} \mathrm{C}$ values of seston during the dry $\left(R^{2}=0.85\right.$, $P<0.01)$ and wet $\left(R^{2}=0.67, P<0.05\right)$ seasons. 
Herbivore-Mediated Subsidies for Riverine Consumers
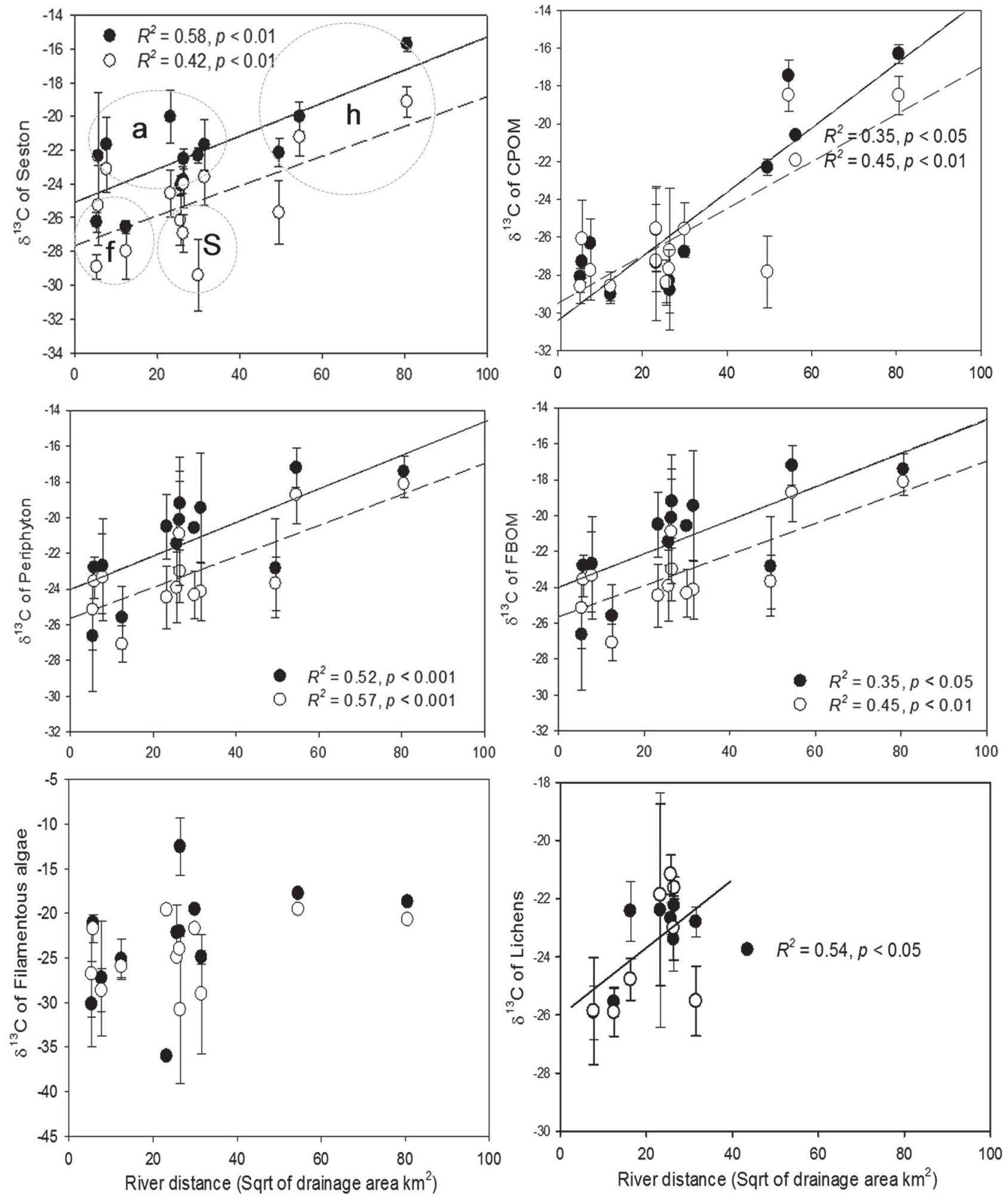

Figure 2. Spatio-temporal variability in the $\delta^{13} \mathrm{C}$ of seston, CPOM, periphyton, FBOM, filamentous algae, and lichens in the Mara River and its tributaries. Lines are significant linear regression relationships; dotted lines and open circles wet season, full line and shaded circles dry season. Single measurements per site do not have error bars. Dotted circles enclose sites under similar influences and apply to all panels. $\mathrm{a}=$ agriculture and livestock; $\mathrm{f}=$ forest; $\mathrm{s}=$ savanna livestock and agriculture; $\mathrm{h}=$ hippos and savanna grasslands. 
Table 4. Results of Stepwise Multiple Regression Analysis for $\delta^{13} \mathrm{C}$ of Seston, Fine Benthic Organic Matter (FBOM), Coarse Particulate Organic Matter (CPOM), Filamentous Algae, and Periphyton as Independent Variables Against Number of Herbivores, \% C4 Cover (Grasslands and Grazing Lands) and River Distance (RDS)

\begin{tabular}{|c|c|c|c|c|}
\hline Dependent variable & Independent variable & Parameter estimate (SE) & $R^{2}$ & $P$ value \\
\hline \multicolumn{5}{|l|}{ Dry season } \\
\hline \multirow[t]{4}{*}{ Seston } & Intercept & $2.431(0.098)$ & & \\
\hline & Number of herbivores & $0.111(0.031)$ & 0.83 & 0.022 \\
\hline & $\%$ C4 cover & $0.400(0.163)$ & 0.10 & 0.070 \\
\hline & Full model & & 0.93 & 0.005 \\
\hline \multirow[t]{2}{*}{ FBOM } & Intercept & $2.378(0.102)$ & & \\
\hline & Number of herbivores & $0.154(0.027)$ & 0.86 & 0.003 \\
\hline \multirow[t]{2}{*}{ СРОМ } & Intercept & $2.497(0.118)$ & & \\
\hline & $\%$ C4 cover & $1.242(0.509)$ & 0.54 & 0.059 \\
\hline \multirow[t]{2}{*}{ Filamentous algae } & Intercept & $2.160(0.324)$ & & \\
\hline & RDS & $0.240(0.097)$ & 0.55 & 0.056 \\
\hline \multirow[t]{4}{*}{ Periphyton } & Intercept & $2.339(0.079)$ & & \\
\hline & Number of herbivores & $0.106(0.024)$ & 0.88 & 0.012 \\
\hline & RDS & $0.075(0.031)$ & 0.07 & 0.076 \\
\hline & Full model & & 0.95 & 0.003 \\
\hline \multicolumn{5}{|l|}{ Wet season } \\
\hline \multirow[t]{2}{*}{ Seston } & Intercept & $2.088(0.273)$ & & \\
\hline & Number of herbivores & $0.173(0.073)$ & 0.53 & 0.065 \\
\hline \multirow[t]{4}{*}{ FBOM } & Intercept & $2.279(0.087)$ & & \\
\hline & Number of herbivores & $0.134(0.027)$ & 0.89 & 0.008 \\
\hline & $\%$ C4 cover & $0.039(0.145)$ & 0.06 & 0.100 \\
\hline & Full model & & 0.95 & \\
\hline \multirow[t]{2}{*}{ СРOM } & Intercept & $1.746(0.250)$ & & \\
\hline & RDS & $0.289(0.075)$ & 0.75 & 0.012 \\
\hline \multirow[t]{2}{*}{ Periphyton } & Intercept & $2.312(0.149)$ & & \\
\hline & Number of herbivores & $0.153(0.040)$ & 0.75 & 0.012 \\
\hline
\end{tabular}

\section{Consumer Groups}

Different trophic guilds had different $\delta^{13} \mathrm{C}$ and $\delta^{15} \mathrm{~N}$ values across sites, and dry season values were generally higher than wet season values. The Ngetuny forest site recorded the lowest $\delta^{13} \mathrm{C}$ values (range -26.9 to $-24.7 \%$ ) for macroinvertebrates, and these were within values recorded for periphyton and C3 producers (Supplementary Table S1). The lowest $\delta^{13} \mathrm{C}$ value for fishes in the dry season was $-22.8 \%$. Tenwek agricultural site had low $\delta^{13} \mathrm{C}$ values for filterers $(-25.6 \%$ o $)$, scrapers $(-22.6 \pm 1.9 \%)$, and shredders $(-25.0 \%)$ during the wet season. At the agricultural Issey and Kapkimolwa sites, $\delta^{13} \mathrm{C}$ values for macroinvertebrates were generally higher in the dry season than in the wet season, while there were no differences in $\delta^{15} \mathrm{~N}$ values between the seasons. However, insectivorous and omnivorous fishes did not display any seasonal variability in their $\delta^{13} \mathrm{C}$ or $\delta^{15} \mathrm{~N}$ values. At the Mara Main site, consumers had the highest $\delta^{13} \mathrm{C}$ values (range -20.3 to $-14.5 \%$ ) and, in general, $\delta^{13} \mathrm{C}$ values were higher in the wet season. Conversely, consumer $\delta^{15} \mathrm{~N}$ values were generally lower than those at rest of the sites, only comparable to those recorded at Ngetuny site.

\section{Stable Isotope Mixing Models}

Simple linear regression relationships showing the influence of river distance and number of herbivores per $\mathrm{km}^{2}$ on the modal contributions of $\mathrm{C} 3$ producers, C4 producers, and periphyton, scraper/ grazer macroinvertebrates, and insectivorous fishes based on Bayesian mixing models are graphically presented for illustration (Figure 5). There were significant positive relationships $(P<0.05)$ between the estimated proportion of $\mathrm{C} 4$ vegetation cover in the catchment and the importance of $\mathrm{C} 4$ producers to macroinvertebrate collector-filterers, collector-gatherers, predatory macroinvertebrates, and insectivorous fishes during the wet season and 
Herbivore-Mediated Subsidies for Riverine Consumers
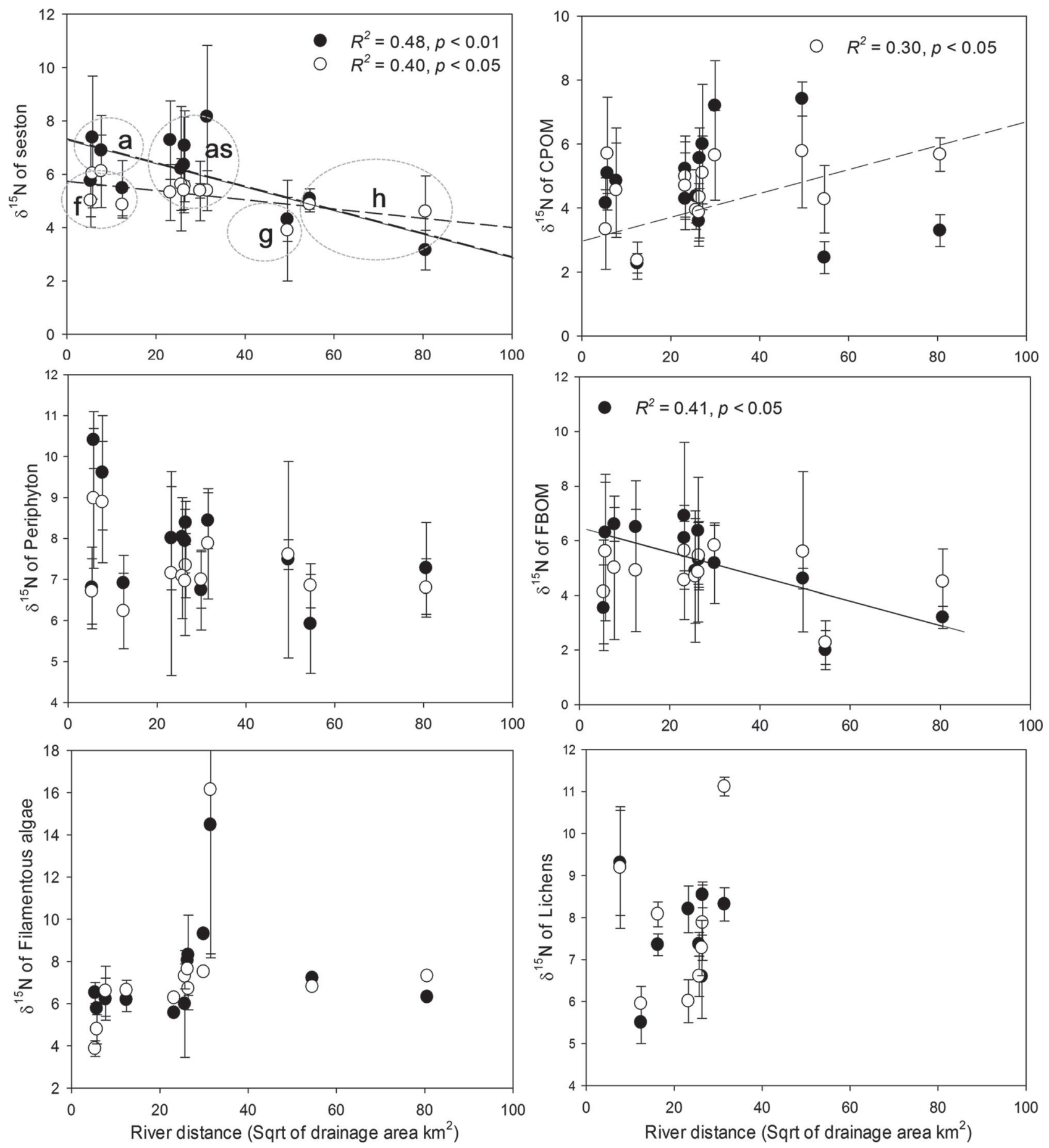

Figure 3. Spatio-temporal variability in the $\delta^{15} \mathrm{~N}$ of seston, CPOM, FBOM, periphyton, filamentous algae, and lichens in the Mara River and its tributaries. Lines are linear regression relationships; dotted lines and open circles wet season, full line and shaded circles dry season. Single measurements per site do not have error bars. Dotted circles enclose sites under similar influences and apply to all panels. $\mathrm{a}=$ agriculture and livestock; $\mathrm{f}=$ forest; $\mathrm{s}=$ savanna livestock and agriculture; $\mathrm{g}=$ savanna grazing rangelands; $\mathrm{h}=$ savanna grasslands and hippos. 

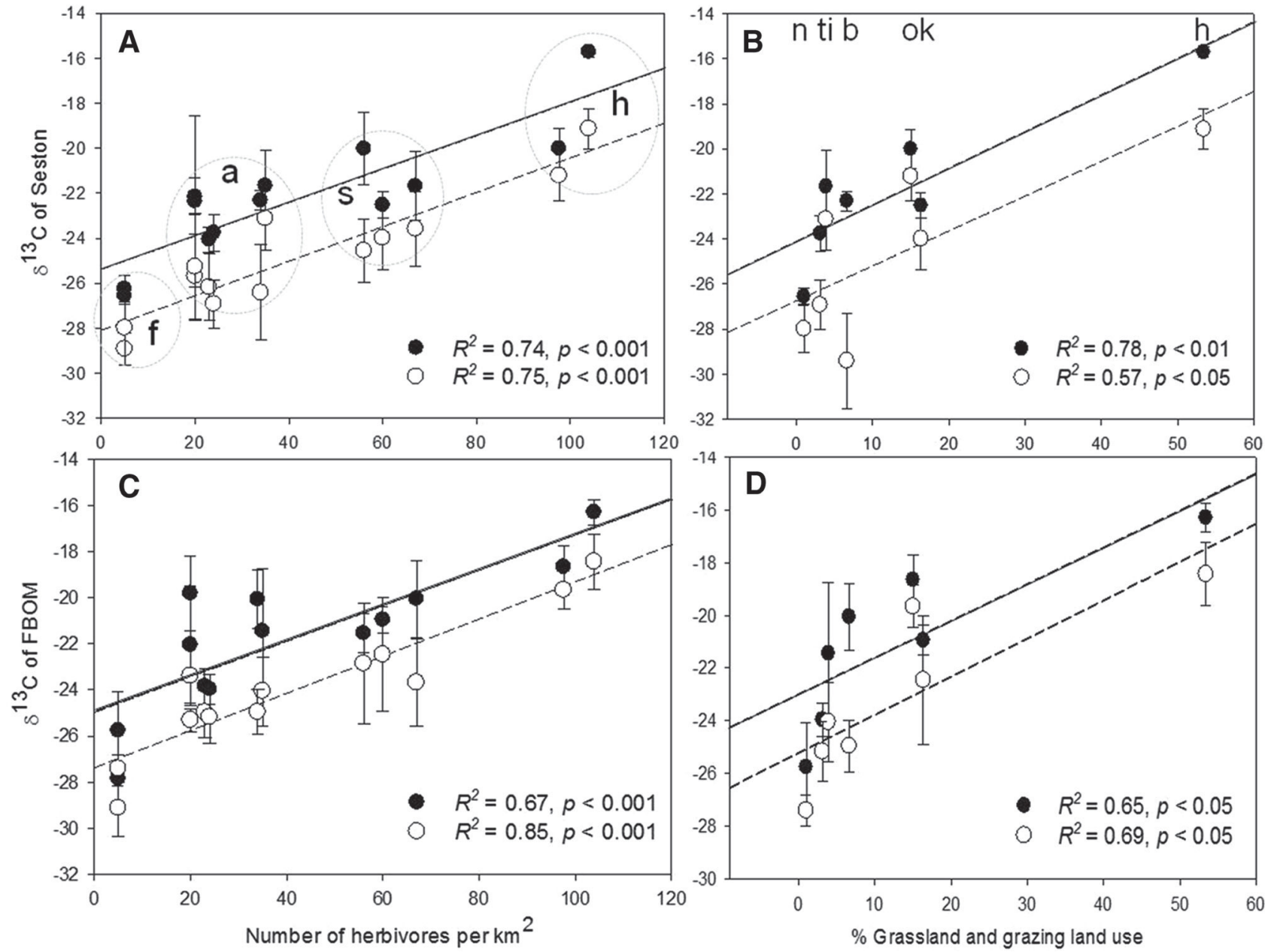

Figure 4. Relationships between number of herbivores per $\mathrm{km}^{2}$ and $(\mathbf{A}) \delta^{13} \mathrm{C}$ of seston and (C) FBOM, and relationships between the percentage of grassland and grazing land use and $(\mathbf{B}) \delta^{13} \mathrm{C}$ of seston and of $(\mathbf{D})$ fine benthic organic matter (FBOM) in the Mara River and its tributaries. Lines are significant linear regression relationships; full line and shaded circles are for dry season; dotted lines and open circles are for the wet season. Dotted circles enclose sites under similar influences and apply to panels $(\mathbf{A})$ and $(\mathbf{C})$. $\mathrm{a}=$ agriculture and livestock; $\mathrm{f}=$ forest; $\mathrm{s}=$ savanna livestock and agriculture; $\mathrm{h}=$ savanna grasslands and hippos; small letter across panel $(\mathbf{B})$ are for site names in Table 1 and also apply to panel $(\mathbf{D}): \mathrm{n}=\mathrm{Ngetuny}$; $\mathrm{t}=$ Tenwek; $\mathrm{I}=$ Issey; $\mathrm{b}=$ Olbutyo; $\mathrm{o}=\mathrm{OMB} ; \mathrm{k}=$ Kapkimolwa; $\mathrm{h}=\mathrm{NMB}$.

to macroinvertebrate scrapers during the dry season as estimated by the Bayesian mixing models (Figure 6).

Overall, model results indicate that periphyton dominated contributions to macroinvertebrates and fishes in the Mara River during the dry season (summarized in Figure 7). The importance of terrestrial C3, C4, and autochthonous production (mainly periphyton) differed between consumer groups, sites, and seasons (Supplementary Table S2). During the dry season, periphyton, and C3 producers were the main sources for invertebrate filterers at the forest site with 25-86\% (95\% credibility interval (CI)) contribution, while the three sources (C3, C4, and periphyton) were all important for insectivorous fishes. At Tenwek site, periphyton and lichens were the main sources for filterers (5-51 and 8-53\%, respectively) and insectivorous fishes (20-57 and 23-62\%, respectively). At Issey and Kapkimolwa sites, periphyton was the main source for most consumers. At the Olbutyo site, periphyton was the main source for insectivorous fishes with a contribution of $28-75 \%$. All sources (periphyton and C3 and C4 producers) were important for shredders, filterers, gatherers, and predatory invertebrates at the site. At the Mara Main site, periphyton and C4 sources were equally important for filterers with 3-76 and 11-75\% contributions, respectively. Source contributions were similar for predatory invertebrates during the 

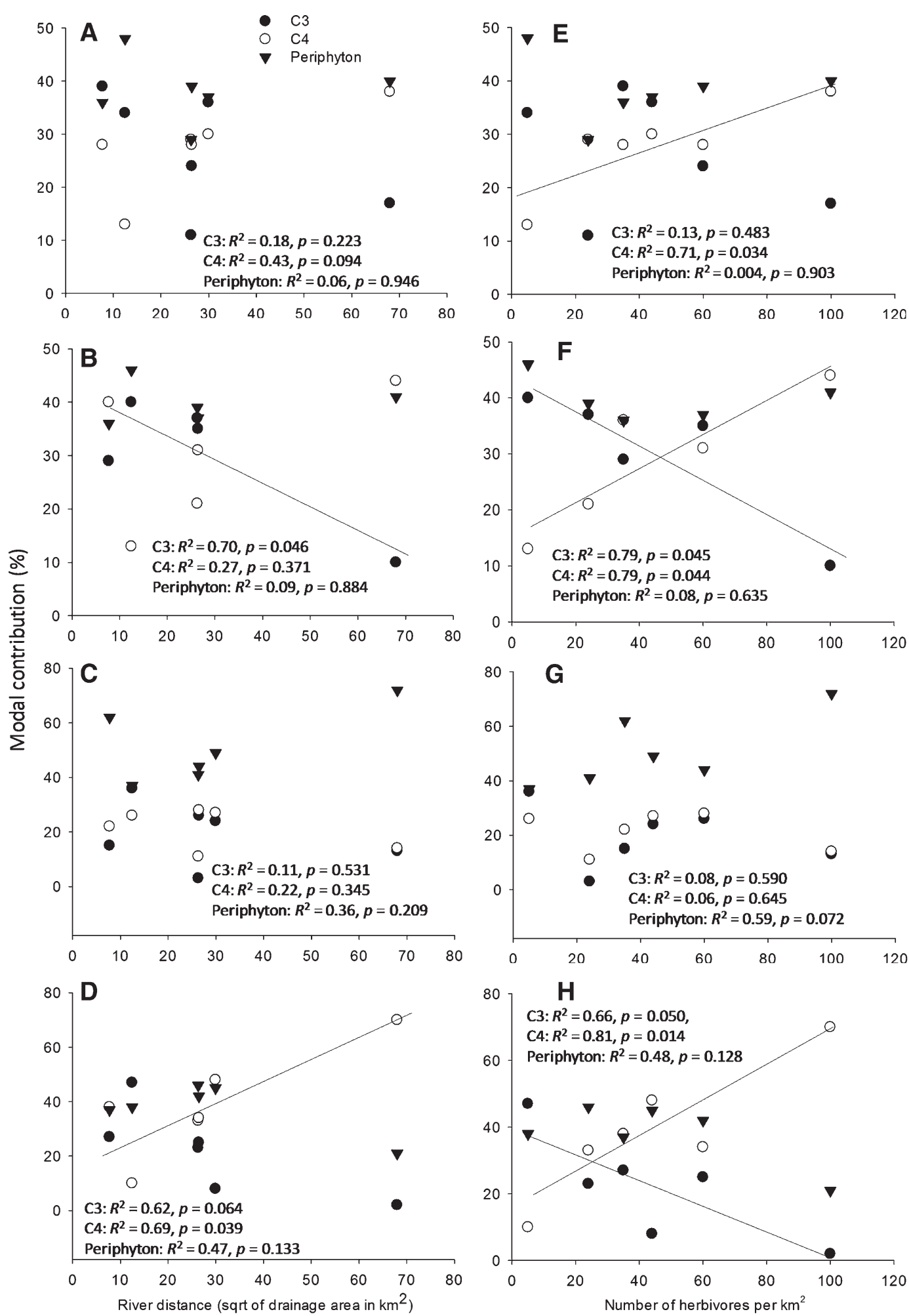

Figure 5. Simple linear regression relationships between river distance (square root of drainage area in $\mathrm{km}^{2}$ ) and number of herbivores per $\mathrm{km}^{2}$ (herbivore density) and the modal contribution (based on Bayesian mixing models) of C3 producers, C4 producers, and periphyton for scraper/grazer macroinvertebrates $(\mathbf{A}, \mathbf{B}, \mathbf{E}, \mathbf{F})$ and insectivorous fishes $(\mathbf{C}, \mathbf{D}, \mathbf{G}, \mathbf{H})$ during the $\operatorname{dry}(\mathbf{A}, \mathbf{C}, \mathbf{E}, \mathbf{G})$ and wet $(\mathbf{B}, \mathbf{D}, \mathbf{F}, \mathbf{H})$ seasons. Significant relationships are indicated with full lines. 
dry season but the importance of periphyton was higher for insectivorous fishes (28-75\%).

During the wet season, notable shifts were observed with $\mathrm{C} 4$ producer-dominating sites influenced by higher numbers of livestock and hippos (Supplementary Table S2). For most consumer groups at the forest Ngetuny site, C3 producers and periphyton were important, although the 95\% CI of some contributions included $0 \%$. At Issey site, the importance of periphyton was lower in the wet
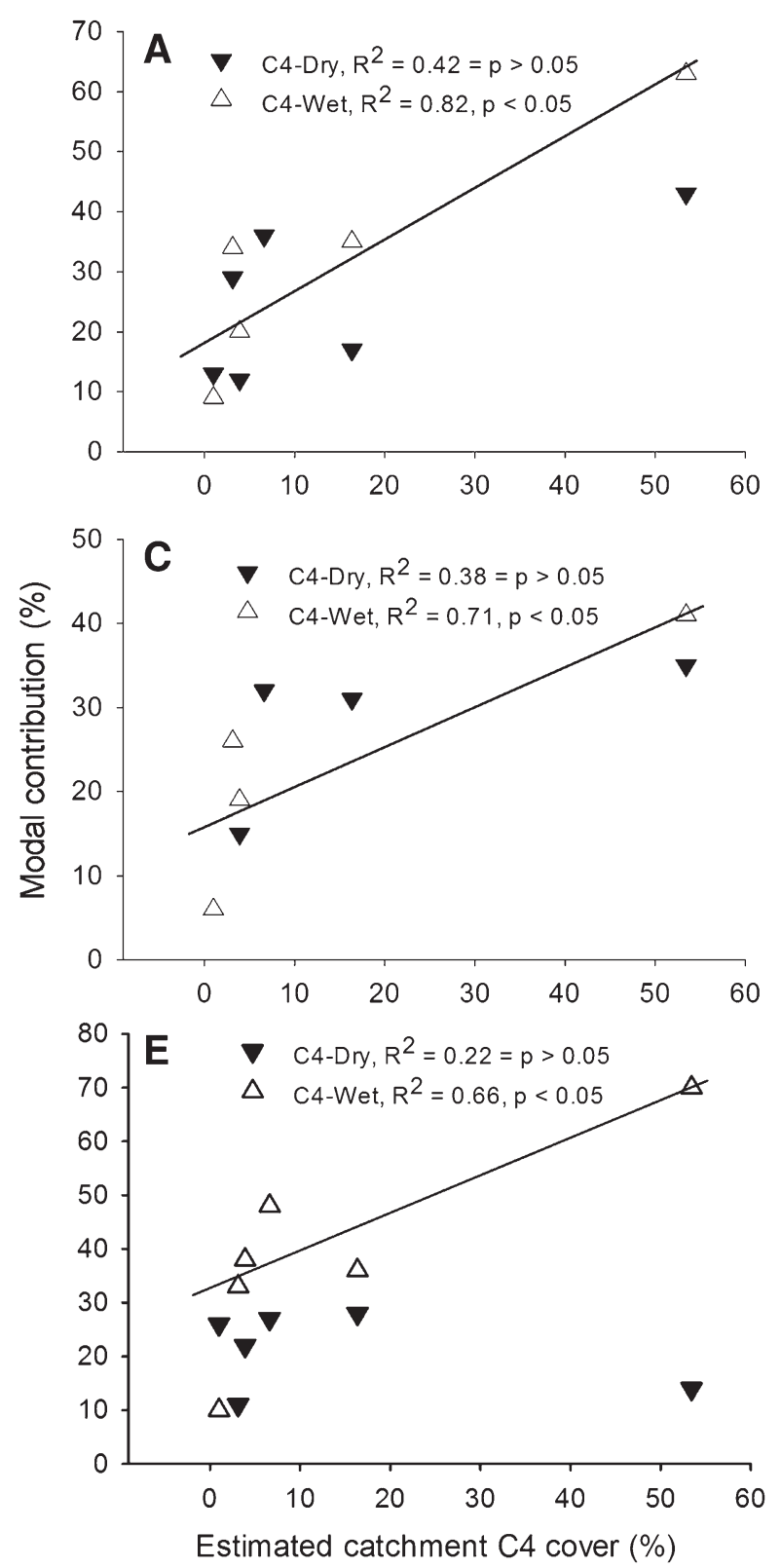

than in the dry season for filterers and insectivorous fishes whereas that of C4 producers was higher; the importance of other sources for the rest of the consumer groups displayed mixed patterns. However, for most of the consumer groups, C4 producers were important during the dry season whereas C3 producers were important during the wet season (Supplementary Table S2). During the wet season, C3 producers were the main source for shredders $(21-63 \%)$. At Kapkimolwa site, the
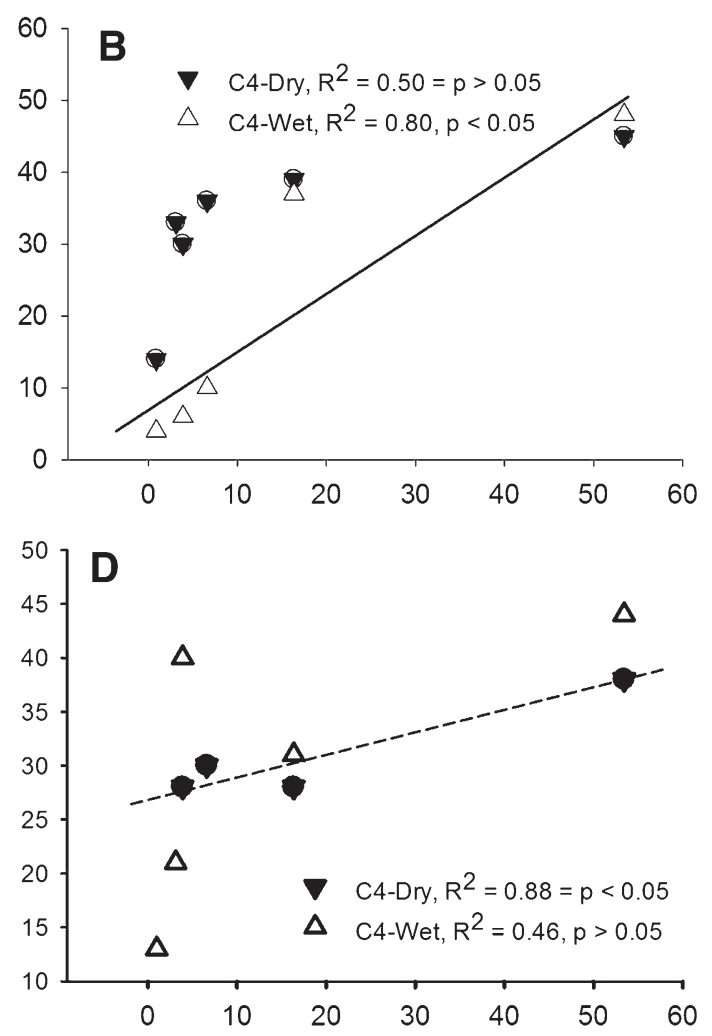

Estimated catchment C4 cover (\%)

Figure 6. Simple linear regression (SLR) relationships between the estimated proportion of C4 vegetation cover in the catchments and the modal contribution (based on Bayesian mixing models) of C4 producers for (A) collector-filterers, (B) collector-gatherers, $(\mathbf{C})$ predatory macroinvertebrates, $(\mathbf{D})$ macroinvertebrate scrapers, and (E) insectivorous fishes during the dry and wet seasons. Significant relationships are indicated; full line wet season, short dotted line dry season. 


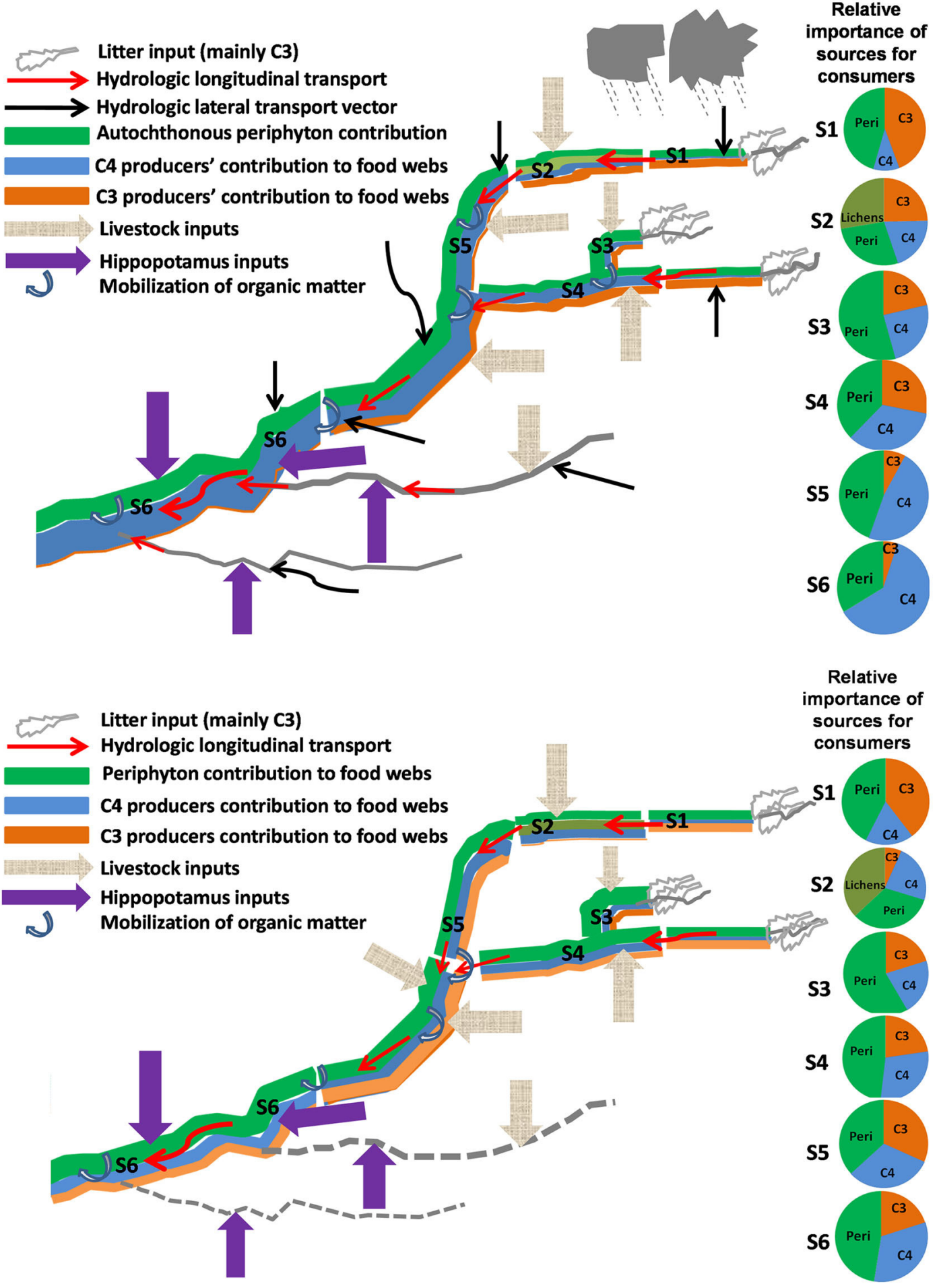

Figure 7. SIAR estimated wet (top) and dry (bottom) season contributions of C3 and C4 producers, lichens, and periphyton (peri) to consumers in the Mara River. The width of the different colors is proportional to the average contributions of the four sources of carbon to macroinvertebrates and fishes in the immediate river reaches. The importance of herbivore-mediated C4 carbon for consumers has been interpreted as a direct contribution via a detrital pathway, but it may also reflect a shift in the $\delta^{13} \mathrm{C}$ values of a dominant algal source. The pie charts represent the proportions averaged for different consumer groups per site (S1 = Ngetuny; S2 = Tenwek; S3 = Issey; S4 = Kapkimolwa; S5 = Olbutyo; S6 = Mara Main. The gray lines represent the river network not considered during this study; the dotted lines represent seasonal tributaries that are sources of hippo and livestock subsidies only during the wet season. The arrows for livestock and hippo inputs do not represent the actual input values. 
importance of C3 and C4 producers increased for all consumers during the wet season, except for insectivorous fishes where $\mathrm{C} 4$ contributions reduced from 17-37 to 5-38. At Olbutyo site, periphyton $(27-54 \%)$ and C4 producers (44-52\%) were equally important for insectivorous fishes. At the Mara Main site, C4 sources dominated for all consumers during the wet season. The importance of C4 producers for insectivorous fishes increased from $1-37$ to $57-82 \%$ from the dry season to the wet season, whereas that of periphyton reduced from $40-94$ to $1-41 \%$. Similarly, the importance of C4 producers for omnivorous fishes increased from $10-42$ to $51-77 \%$ whereas that of periphyton reduced from $40-84$ to $9-48 \%$.

\section{Discussion}

Studies that address energy flow in riverine food webs are important to identify specific habitats and energy sources that underpin productivity (Naiman and others 2012). This study shows that the relative importance of different sources of energy for consumers in the Mara River is spatially and seasonally variable. Different trophic groups relied on different energy sources to different extents, indicating significant spatial and taxonomic variation in sources of nutrition (compare Zeug and Winemiller 2008; Pingram and others 2014). Macroinvertebrate filterers were good indicators of upstream sources and reflected the dominant terrestrial energy sources at the vicinity of the sites (either C3 or C4 producers). On the other hand, macroinvertebrate gatherers and insectivorous fishes captured the immediate influences at the sampled river reaches during the dry season. Overall, periphyton was the major source of energy at most of the sites during the dry season, partly in agreement with long-held concepts of river ecology: the river continuum concept (Vannote and others 1980) and the riverine productivity model (Thorp and Delong 1994). However, there is a potential for incorporation of C4-derived carbon to consumers via an algal pathway (details below), which would have potentially increased the modeled importance of algae for consumers, but this was not resolved due to lack of $\delta^{13} \mathrm{C}$ data on dissolved inorganic carbon (DIC). During the dry season, the importance of C4 relative to $\mathrm{C} 3$ producers was slightly lower at the hippo-influenced site but much more important during the wet season (Figure 7). At the agricultural sites (Issey, Tenwek, Olbutyo and Issey-supplementary Table S2), the relative importance of $\mathrm{C} 4$ relative to $\mathrm{C} 3$ producers for most consumers was higher during the dry season. In contrast, a range of previous studies suggest that $\mathrm{C} 4$ producers contribute minimally as an energy source to consumer biomass as compared with C3 producers and autochthonous (algae and periphyton) producers (Clapcott and Bunn 2003; Abrantes and Sheaves 2010; Roach 2013).

There were significant relationships between the estimated proportion of $\mathrm{C} 4$ vegetation in the catchments and the importance of $\mathrm{C} 4$ producers to most consumer groups during the wet season (Figure 6). The relationships would have been stronger if the mainstem Mara River sites (OMB and NMB) were not combined (for example, Figures 2,4). Similarly, in the C4-dominated Tana and Betsiboka River basins, C4 producers were the main sources for all trophic groups at the estuaries (Abrantes and others 2013). The relatively high importance of $\mathrm{C} 4$ terrestrial producers to riverine food webs in African systems such as the Mara River savanna is likely to be partly a result of the activities of herbivores, which work as vectors of transfer of C4 terrestrial subsidies into streams and rivers, as these animals tend to congregate near water bodies. Indeed, the high $\delta^{13} \mathrm{C}$ values of $\mathrm{OM}$ at agricultural and savanna sites in this study indicate that this is mostly of C4 origin, at least in part resulting from the transport of $\mathrm{C} 4$ material into waterways by watering animals (both wild animals and livestock), after grazing on grasses. Herbivore density was a major predictor of $\delta^{13} \mathrm{C}$ values of seston, FBOM, and periphyton in the Mara River during the dry and wet seasons, further highlighting the potentially important role played by large mammalian herbivores in the organic matter dynamics and energy sources for consumers in the river. The influence of hippos as vectors of terrestrial organic matter that fuel food webs in Africa's aquatic ecosystems is receiving increased attention (Gereta and Wolanski 1998; Grey and Harper 2002; Mosepele and others 2009, Pennisi 2014). Inside and outside the MMNR, large populations of hippos (4143 individuals, Kanga and others 2011) graze on terrestrial savanna C4 grasses during the night and excrete partially digested excreta in the Mara River and its tributaries during the day. Recent estimates show that an average hippo defecates $8.7 \mathrm{~kg}$ (wet weight) of terrestrial organic matter into the Mara River daily, which translates into around 36,000 kg of hippo feces (wet weight) daily (Subalusky and others 2014). A study during the wet season has estimated that $3-11 \%$ of the suspended sediments in the Mara River at the NMB site are contributed by hippo feces (Dutton 2012). However, the importance of terrestrial $\mathrm{C} 4$ carbon relative to autochthonous production should be interpreted with 
caution, given that the ${ }^{13} \mathrm{C}$-enriched values of periphyton could also be partially explained by a contribution of $\mathrm{CO}_{2}$ resulting from the respiration of $\mathrm{C} 4$ inputs to the inorganic $\mathrm{C}$ pool fixed by algae during photosynthesis (Rau 1978; Jepsen and Winemiller 2007). In this study, the importance of herbivore-mediated C4 carbon for consumers has been interpreted as a direct contribution via a detrital pathway, but it may also reflect a shift in the $\delta^{13} \mathrm{C}$ values of a dominant algal source. In cases where the $\delta^{13} \mathrm{C}$ values of periphyton and C4 converge and are not very distinct, as in the Mara Main site, uncertainty arises in the modeled importance of sources because they are interpreted by the SIAR model to be all important for consumers (Fry 2013; Brett 2014).

The findings of our study are contrary to catchments where, in the absence of large herbivores, the contribution of $\mathrm{C} 4$ carbon to river systems is more limited than expected based on areal cover (Abrantes and Sheaves 2010; Marwick and others 2014b). Without herbivore-mediated inputs, we would expect to see a disproportionately higher proportion of C3 inputs compared with C4 inputs at agricultural sites (Issey, Tenwek, Kapkimolwa, and Olbutyo) during the dry season because surface runoff is reduced and the proportional contribution of riparian vegetation (river zone contains more C3 vegetation than at further distance from the river course) would increase. The $\delta^{15} \mathrm{~N}$ values for basal resources were also higher at agricultural sites (as high as $16 \%$, Figure 3), suggesting a significant input of nitrates from agriculture and animal excreta (for example, Anderson and Cabana 2005). At the hippo-influenced Mara Main site, C4 producers gained more importance for insectivorous and omnivorous fishes during the wet season, but contributions to macroinvertebrate groups are mixed for the three sources (Supplementary Table S2). During the dry season, it would be expected that inputs mediated by hippos, which are constant throughout the year, would be most important relative to the wet season. However, during the dry season, flow levels in the river significantly drop (McClain and others 2014), and much of the hippo excreta likely settle out. The slow movement of water in backwaters coupled with hippo fertilization (nutrient input) have been noted to increase primary production (Gereta and Wolanski 1998). During the wet season, increased turbidity through scouring and mobilization of hippo excreta in pools by elevated flow levels, coupled with additional C4 organic matter input from savanna grasslands by surface runoff, would limit primary production and make terrestrial inputs to dominate contributions to consumers (for example, Mead and Wiegner 2010; Abrantes and others 2013). Moreover, the entire gradient of the studied river is incised with minimal interaction with the floodplain. This makes the possibility of floodplain-derived ${ }^{13} \mathrm{C}$ enriched algal organic matter contributing to food webs that would confound the role of herbivores unlikely. However, during the wet season, there is also a likelihood of terrestrial arthropods to be transported into the river by water and/or wind (Balcombe and others 2005). These sources coming from C4-dominated habitats can contribute significantly to insectivorous fishes (Nakano and others 1999; Forsberg and others 1993; Bunn and others 1997) but were not sampled in our study. Another potential input of $\mathrm{C} 4$ sources into the river is the many carcasses of wildebeests that drown in the river during their annual migrations. The crossing points for the wildebeests are between OMB and NMB sites, but this pulse subsidy was not captured in this study as shown by the similar values for producers and consumers at the $\mathrm{OMB}$ and NMB sites. Findings that macroinvertebrates relied on a mixture of sources (periphyton, C3 and C4 producers) can be explained by the shorter carbon and nitrogen half-lives (weeks) for invertebrates (McIntyre and Flecker 2006; Dubois and others 2007), which enables shifts in stable isotope composition to be detected within weeks of change in diet, as compared with the mature fishes captured in this study with half-lives of 1-3.5 months (Buchheister and Latour 2010; Weidel and others 2011).

So as not to bias our interpretations on the important role of herbivores as vectors of delivery of C4 OM from catchments into river reaches and food webs, it is important to consider possible contributions from autochthonous sources, which can contribute significantly to riverine OM pools (Lewis and others 2001), as well as the possibility that periphyton samples were not entirely composed of algal organic matter. Macrophytes were absent from the sample areas and the $\delta^{13} \mathrm{C}$ values of periphyton $[-25.8 \pm 1.8$ to $-17.3 \pm 0.9 \%( \pm S D)]$ and filamentous algae (generally -36.0 to $-17.8 \%$, with a single sample with a value of $-12.5 \%$ ) were low during the dry season, even lower in the wet season (Figure 2), and in the range of the $\mathrm{C}_{3}$ photosynthetic pathway. This implies that any possible contribution of autochthonous sources would most likely have been added to the contributions of C3 sources, rather than $\mathrm{C} 4$, so overall results from this study would not be affected.

The fraction of detritus in periphyton can be high in unproductive and turbid rivers (McIntyre and 
Flecker 2006; Rasmussen 2010), but epilithic grazers selectively assimilate the autochthonous component from periphyton (Finlay 2001; McIntyre and Flecker 2006). This implies that estimates of autochthonous contributions to consumers will be underestimated if isotopic signatures of bulk periphyton are used in mixing models. To ensure that the algal samples were as free of other organic matter as possible, periphyton samples were thoroughly cleaned of visible non-algal material.

Another possible source of bias concerning contributions of autochthonous sources to consumers relates to the possibility of a downstream enrichment in ${ }^{13} \mathrm{C}$ of periphyton and algae in rivers that is independent of large herbivores, which can lead to overlap with signatures of allochthonous terrestrial detritus (Finlay 2001; Rasmussen and others 2009; Rasmussen 2010). Although this has the potential to influence the findings of this study, findings from the Tana and Athi-Galana-Sabaki rivers in Kenya indicate that the longitudinal changes in the drivers of $\delta^{13} \mathrm{C}$ of autochthonous producers, such as $\delta^{13} \mathrm{C}_{\text {DIC }}$, are complex and non-linear (for example, Bouillon and others 2009; Tamooh and others 2013). Additionally, stepwise MLR (Table 4) show that RDS is only marginally related to longitudinal changes in the $\delta^{13} \mathrm{C}$ of filamentous algae and periphyton, implying that other factors played a larger role. In the Lake Victoria basin, an isotopic study in a number of river systems under different influences of terrestrial $\mathrm{C} 4$ sources did not capture longitudinal enrichment of $\delta^{13} \mathrm{C}$ of periphyton / algae that would confound estimates of contributions of C4 terrestrial sources for Barbus altianalis and Labeo victoriae fishes (Ojwang and others 2007). Instead, fishes downstream of sites receiving effluents (C4 carbon) from sugarcane processing recorded enriched $\delta^{13} \mathrm{C}$ values that were similar to values at hippo-influenced sites in this study. Although uncommon, these findings show that $\mathrm{C} 4$ resources can be major sources of energy in some rivers. Elsewhere in the tropics, some fishes are known to incorporate C4 sources in their diets, such as Schizodon fasciatus from the Amazon River (Forsberg and others 1993) and Schizodon isognatus from a floodplain lake in Venezuela (Jepsen and Winemiller 2007).

Losses of mega-herbivore species from major land masses worldwide have had a significant influence on vegetation patterns and organic matter dynamics, nutrient distributions, and ecosystem functioning (Zimov 2005; Wardle and others 2011). In Africa, large populations of savanna herbivores have been decimated and replaced by exotic livestock, which now make up more than $90 \%$ of large mammalian biomass of east and southern Africa (Prins 2000). This loss of herbivores makes it difficult to understand predevelopment ecosystem dynamics and establish terrestrial-aquatic food-web linkages, especially those that are mediated by indigenous animal vectors. It has been predicted for African savannas that a substantial reduction in large herbivore diversity will result in significant changes in ecosystem structure and function as well as a cascading decline in terrestrial savanna biodiversity ( $\mathrm{du}$ Toit and Cumming 1999). Along river valleys, reciprocal flows of subsidies by animals, or through their game paths along which materials flow from terrestrial landscapes to rivers, have also been reported (Jacobs and others 2007). The large populations of herbivores in African savanna systems, such as the Mara-Serengeti ecosystem in East Africa, offer opportunities to study and infer the role of large herbivores on riverine ecosystem functioning (Naiman and Rogers 1997). Thus, this study offers a glimpse into the past and, at the same time, presents evidence for the ever increasing anthropogenic influence on riverine ecosystems structure and function.

Most rivers draining into Lake Victoria have been cleared of hippo populations, which are currently confined to river mouths of major rivers and littoral areas around the lake and in many places they have been replaced by cattle (Masese and McClain 2012). The disparate conditioning of ingested organic matter by these two herbivores likely influences nutrient cycling and ecosystem dynamics, but comparative studies are limited. For instance, as ruminants, cattle rework their ingested food when chewing the cud, resulting in a more refined and homogenous excreta, whereas hippos excrete semi-digested material. In the Mara River, hippos have been associated with increased primary and secondary production (Gereta and Wolanski 1998), but details on the influence of the expanding livestock numbers are limited.

\section{Conclusions}

Partitioning the relative importance of different sources of energy supporting riverine food webs is useful for their management and restoration (Naiman and others 2012). This study highlights the important role that terrestrial herbivores play as vectors of terrestrialaquatic food-web linkages in African savanna landscapes and the importance of considering seasonality in riverine food web studies. Despite some uncertainty in the modeled contributions of $\mathrm{C} 4$ producers and periphyton to consumers in some sections of the Mara River due to converging $\delta^{13} \mathrm{C}$ values and unresolved pathways of incorporation of $\mathrm{C} 4$ carbon into consumer 
biomass, it is unequivocal that large mammalian herbivores have a major influence on the biogeochemistry of the river and food webs via inputs of terrestrial C4 carbon. We show that both terrestrial and autochthonous sources fuel aquatic food webs, and that these resources are highly spatially and seasonally variable. Future research work in the Mara and similar savanna river systems that receive terrestrial OM subsidies mediated by large mammalian herbivores should consider additional isotopes such as $\delta \mathrm{D}$ and $\delta^{34} \mathrm{~S}$ to better differentiate autochthonous and allochthonous sources (Doucett and others 2007; Finlay and others 2010). There is also a need to consider biogeochemical variables along these systems when making upstream-downstream comparisons and interpretations based on isotopic data (Jepsen and Winemiller 2007). These will help address longitudinal natural changes in $\delta^{13} \mathrm{C}$ autochthonous resources that may confound estimates of contributions of terrestrial $\mathrm{C} 4$ resources to consumers. The importance of different sources for consumer groups depends on the nature of herbivore and human influences, pathways of energy flow, season and location on the fluvial continuum, and highlights a need to further examine the interaction among discharge variation, animal-mediated subsidies, and taxonomic diversity for the preservation of key ecological functions in rivers of the region.

\section{ACKNOWLEDGMENTS}

We are grateful to Lubanga Lunaligo and David Namwaya (University of Eldoret) for assistance during lab work, William O. Ojwang and Chrisphine Nyamweya (KMFRI, Kisumu) and their team who assisted during fieldwork. We thank Zita Kelemen (KU Leuven), Amanda Subalusky, and Glendon Hunsinger (Yale University) for SIA analyses. We thank the TransMara Conservancy and the Narok County Council (Narok County) for granting us access into the Mara Triangle and MMNR, respectively. Insightful comments and suggestions by the subject editor Dr. S. Bunn and two anonymous reviewers significantly improved this manuscript. This is a publication of the MaraFlows Project and was funded by the Dutch Ministry of Foreign Affairs through UNESCO-IHE Partnership Research Fund (UPaRF). Partial support was provided by ERC-StG 240002 (AFRIVAL).

\section{REFERENCES}

Abrantes KG, Barnett A, Marwick TR, Bouillon S. 2013. Importance of terrestrial subsidies for estuarine food webs in contrasting East African catchments. Ecosphere 4: Article 14.
Abrantes KG, Sheaves M. 2010. Importance of freshwater flow in terrestrial-aquatic energetic connectivity in intermittently connected estuaries of tropical Australia. Mar Biol 157(2071):2086.

Anderson C, Cabana G. 2005. $\delta^{15} \mathrm{~N}$ in riverine food webs: effects of $\mathrm{N}$ inputs from agricultural watersheds. Can J Fish Aquat Sci 62:333-40.

APHA (American Public Health Association), 1998. Standard Methods for the Examination of Water and Wastewater, 20th ed. American Public Health Association, American Water Works Association, Water Environment Federation, Washington, DC.

Balcombe SR, Bunn SE, McKenzie-Smith FJ, Davies PM. 2005. Variability of fish diets between dry and flood periods in an arid zone floodplain river. J Fish Biol 67:1552-67.

Bond TA, Sear DA, Edwards ME. 2012. Temperature-driven river utilisation and preferential defecation by cattle in an English chalk stream. Livestock Sci 146:59-66.

Bouillon S, Abril G, Borges AV, Dehairs F, Govers G, Hughes HJ, Merckx R, Meysman FJR, Nyunja J, Osburn C, Middelburg JJ. 2009. Distribution, origin and cycling of carbon in the Tana River (Kenya): a dry season basin-scale survey from headwaters to the delta. Biogeosciences 6:2475-93.

Brett MT. 2014. Resource polygon geometry predicts Bayesian stable isotope mixing model bias. Mar Ecol Prog Ser 514:1-12.

Buchheister A, Latour RJ. 2010. Turnover and fractionation of carbon and nitrogen stable isotopes in tissues of a migratory coastal predator, summer flounder (Paralichthys dentatus). Can J Fish Aquat Sci 67:445-61.

Bunn SE, Davies PM, Kellaway DM. 1997. Contributions of sugarcane and invasive pasture grass to the aquatic food web of a tropical lowland stream. Mar Freshw Res 48:173-9.

Bunn SE, Leigh C, Jardine TD. 2013. Diet-tissue fractionation of $\delta^{15} \mathrm{~N}$ by consumers from streams and rivers. Limnol Oceanogr 58:765-73.

Clapcott JE, Bunn SE. 2003. Can C-4 plants contribute to aquatic food webs of subtropical streams? Freshw Biol 48:1 105-16.

Corbet PS. 1961. The food of non-cichlid fishes in the Lake Victoria basin, with remarks on their evolution and adaptation to lacustrine conditions. Proc Zool Soc Lond 136:1-101.

DDP (District Development Plan). 2008a. Effective management for sustainable economic growth and poverty reduction, Bomet District 2002-2008. Nairobi: Government Printer.

DDP (District Development Plan). 2008b. Effective management for sustainable economic growth and poverty reduction, Narok District 2002-2008. Nairobi: Government Printer.

Defersha M, Melesse AM. 2012. Field-scale investigation of the effect of land use on sediment yield and surface runoff using runoff plot data and models in the Mara River basin, Kenya. Catena 89:54-64.

de Ruiter PC, Wolters V, Moore JC, Winemiller KO. 2005. Food web ecology: playing Jenga and beyond. Science 309:68-71.

Doucett RR, Marks JC, Blinn DW, Caron M, Hungate BA. 2007. Measuring terrestrial subsidies to aquatic food webs using stable isotopes of hydrogen. Ecology 88:1587-92.

Douglas MM, Bunn SE, Davies PM. 2005. River and wetland food webs in Australia's wet-dry tropics: general principles and implications for management. Mar Freshw Res 56:32942.

du Toit JT, Cumming DHM. 1999. Functional significance of ungulate diversity in African savannas and the ecological 
implications of the spread of pastoralism. Biodivers Conserv 8:1643-61.

Dubois S, Jean-Louis B, Bertrand B, Lefebvre S. 2007. Isotope trophic-step fractionation of suspension-feeding species: implications for food partitioning in coastal ecosystems. J Exp Mar Biol Ecol 351:121-8.

Dutton CL. 2012. Sediment fingerprinting in the Mara River: uncovering relationships between wildlife, tourism, and nonpoint source pollution. MSc. thesis, Yale University, USA.

Finlay JC. 2001. Stable-carbon-isotope ratios of river biota: implications for energy flow in lotic food webs. Ecology 82:1052-64.

Finlay JC. 2004. Patterns and controls of lotic algal stable carbon isotope ratios. Limnol Oceanogr 49:850-61.

Finlay JC, Doucett RR, McNeely C. 2010. Tracing energy flow in stream food webs using stable isotopes of hydrogen. Freshw Biol 55:941-51.

Forsberg BR, Arujo-Lima CARM, Martinelli LA, Victoria RL, Bonassi JA. 1993. Autotrophic carbon sources for fish of central Amazon. Ecology 74:643-51.

Fry B, Sherr EB. 1989. $\delta^{13} \mathrm{C}$ Measurements as indicators of carbon flow in marine and freshwater ecosystems. In: Rundel PW, Ehleringer JR, Nagy KA, Eds. Stable isotopes in ecological research. Ecological studies. New York: Springer. p 196-229.

Fry B. 2013. Alternative approaches for solving underdetermined isotope mixing problems. Mar Ecol Prog Series 472:1-13.

Gereta E, Wolanski E. 1998. Wildlife-water quality interactions in the Serengeti National Park, Tanzania. Afr J Ecol 36:1-14.

Grey J, Harper DM. 2002. Using stable isotope analyses to identify allochthonous inputs to Lake Naivasha mediated via the hippopotamus gut. Isot Environ Health Stud 38:245-50.

Jackson AJH, McCarter PS. 1994. A profile of the Mau complex. Nairobi: KIFCON.

Jacobs SM, Bechtold JS, Biggs HC, Grimm NB, Lorentz S, McClain ME, Naiman RJ, Perakis SS, Pinay G, Scholes MC. 2007. Nutrient vectors and riparian processing: a review with special reference to African semiarid Savanna ecosystems. Ecosystems 10:1231-49.

Jardine TD, Pettit NE, Warfe DM, Pusey BJ, Ward DP, Douglas MM, Davies PM, Bunn SE. 2012. Consumer-resource coupling in wet-dry tropical rivers. J Anim Ecol 81:310-22.

Jepsen DB, Winemiller KO. 2007. Basin geochemistry and isotopic ratios of fishes and basal production sources in four neotropical rivers. Ecol Freshw Fish 16:267-81.

Junk WJ, Bayley PB, Sparks RE. 1989. The flood pulse concept in river floodplain systems. In: Dodge DP, Ed. Proceedings of the international large river symposium, Canadian Special Publication of Fisheries and Aquatic Sciences 106:110-127.

Kanga EM, Ogutu JO, Olff H, Santema P. 2011. Population trend and distribution of the vulnerable common hippopotamus Hippopotamus amphibius in the Mara Region of Kenya. Oryx 45:20-7.

Kiambi S, Kuloba B, Kenana L, Muteti D, Mwenda E. 2012. Wet season aerial count of large herbivores in masai mara national reserve and the adjacent community areas (June 2010). Narok: Mara Research Station, Kenya Wildlife Service.

KNBS-IHBS. 2007. Kenya National Bureau of Statistics (KNBS)Kenya Integrated Household Budget Survey (KIHBS) - 2005/ 06. Nairobi: Ministry of Planning and National Development.

KNBS-LS. 2009. Livestock population by type and district. Nariobi: Census KNBS

Lamprey RH, Reid RS. 2004. Expansion of human settlement in Kenya's Maasai Mara: what future for pastoralism and wildlife? J Biogeogr 31:997-1032.
Lewis WMJ, Hamilton SK, Rodriguez MA, Saunders JFI, Lasi MA. 2001. Foodweb analysis of the Orinoco floodplain based on production estimates and stable isotope data. J N Am Benthol Soc 20:241-54.

Logan JM, Jardine TD, Miller TJ, Bunn SE, Cunjak RA, Lutcavage ME. 2008. Lipid corrections in carbon and nitrogen stable isotope analyses: comparison of chemical extraction and modelling methods. J Anim Ecol 77:838-46.

MALP (2009a). Ministry of Agriculture and Livestock Production, Narok South District, Kenya.

MALP (2009b). Ministry of Agriculture and Livestock Production, Bomet District, Kenya.

Marwick TR, Tamooh F, Ogwoka B, Teodoru C, Borges AV, Darchambeau F, Bouillon S. 2014a. Dynamic seasonal nitrogen cycling in response to anthropogenic N-loading in a tropical catchment, Athi-Galana-Sabaki River, Kenya. Biogeosciences 11:443-460.

Marwick TR, Borges AV, Acker KV, Darchambeau F, Bouillon S. 2014b. Disproportionate contribution of riparian inputs to organic carbon pools in freshwater systems. Ecosystems 17:974-89. doi:10.1007/s10021-014-9772-6.

Masese FO, Gettel GM, Kitaka N, Kipkemboi J, Irvine K, McClain ME. 2014. Macroinvertebrate functional feeding groups in Kenyan highland streams: more evidence for a diverse shredder assemblage. Freshw Sci 33:435-50.

Masese FO, McClain ME. 2012. Trophic resources and emergent food web attributes in rivers of the Lake Victoria Basin: a review with reference to anthropogenic influences. Ecohydrology 5:685-707.

Mati BM, Mutie S, Gadain H, Home P, Mtalo F. 2008. Impacts of landuse/ cover changes on the hydrology of the transboundary Mara River, Kenya/Tanzania. Lakes Reserv Res Manage 13:169-77.

McClain ME, Subalusky AL, Anderson EP, Dessu SB, Melesse AM, Ndomba PM, Mtamba JOD, Tamatamah RA, Mligo C. 2014. Comparing flow regime, channel hydraulics and biological communities to infer flow-ecology relationships in the Mara River of Kenya and Tanzania. Hydrol Sci J 59(4):1-19.

McCutchan JH, Lewis WM Jr, Kendall C, McGrath CC. 2003. Variation in trophic shift for stable isotope ratios of carbon, nitrogen, and sulfur. Oikos 102:378-90.

McIntyre PB, Flecker AS. 2006. Rapid turnover of tissue nitrogen of primary consumers in tropical freshwaters. Oecologia 148:12-21.

Mead LH, Wiegner TN. 2010. Surface water metabolism in a tropical estuary, Hilo Bay, Hawaii, USA, during storm and non-storm conditions. Estuaries Coasts 33:1099-112.

Mosepele K, Moyle PB, Merron GS, Purkey DR, Mosepele B. 2009. Fish, floods, and ecosystem engineers: aquatic conservation in the Okavango Delta, Botswana. BioScience 59:53-64.

Naiman RJ, Alldredge JR, Beauchamp DA, Bisson PA, Congleton J, Henny CJ, Huntly N, Lamberson R, Levings R, Merrill EN, Pearcy WG, Rieman BE, Ruggerone GT, Scarnecchia D, Smouse PE, Wood CC. 2012. Developing a broader scientific foundation for river restoration: Columbia River food webs. Proc Nat Acad Sci USA 109(52):21201-7.

Naiman RJ, Rogers KH. 1997. Large animals and system level characteristics in river corridors. BioScience 47:521-9.

Nakano S, Miyasaka H, Kuhara N. 1999. Terrestrial-aquatic linkages: riparian arthropod inputs alter trophic cascades in a stream food web. Ecology 80:2435-41.

Ogutu JO, Piepho H-P, Reid RS, Rainy ME, Kruska RL, Worden JS, Nyabenge M, Hobbs NT. 2010. Large herbivore responses 
to water and settlements in savannas. Ecol Monogr 80:24166.

Ogutu JO, Owen-Smith N, Piepho HP, Said MY. 2011. Continuing wildlife population declines and range contraction in the Mara region of Kenya during 1977-2009. J Zool 285:99_ 109.

Ojwang WO, Kaufman L, Soule E, Asila AA. 2007. Evidence of stenotopy and anthropogenic influence on carbon source for two major riverine fishes of the Lake Victoria watershed. J Fish Biol 70:1430-46.

O'Reilly CM, Hecky RE, Cohen AS, Plisnier PD. 2002. Interpreting stable isotopes in food webs: recognizing the role of time averaging at different trophic levels. Limnol Oceanogr 47:306-9.

Paetzold A, Sabo JL, Sadler JP, Findlay SEG, Tockner K. 2007. Aquatic-terrestrial subsidies along river corridors. In: Wood PJ, Hannah DM, Sadler JP, Eds. Hydroecology and ecohydrology: past, present and future. Chichester: Wiley. p 57-92.

Parnell AC, Inger R, Bearhop S, Jackson AL. 2010. Source partitioning using stable isotopes: coping with too much variation. PLoS One 5:e9672.

Pennisi E. 2014. The river masters: hippos are the nutrient kingpins of Africa's waterways. Science 346(6211):785.

Peterson BJ, Howarth RW, Garritt RH. 1985. Multiple stable isotopes used to trace the flow of organic matter in estuarine food webs. Science 227:1361-3.

Phillips DL, Gregg JW. 2003. Source partitioning using stable isotopes: coping with too many sources. Oecologia 136:261-9.

Pingram MA, Collier KJ, Hamilton DP, Hicks BJ, David BO. 2014. Spatial and temporal patterns of carbon flow in a temperate, large river food web. Hydrobiologia 729:107-31.

Pinnegar JK, Polunin NVC. 1999. Differential fractionation of $\delta^{13} \mathrm{C}$ and $\delta^{15} \mathrm{~N}$ among fish tissue: implication for the study of trophic interactions. Funct Ecol 13:225-31.

Polis GA, Anderson WB, Holt RD. 1997. Toward an integration of landscape and food web ecology: the dynamics of spatially subsidized food webs. Ann Rev Ecol Syst 28:289-316.

Post DM, Layman CA, Arrington DA, Takimoto G, Quattrochi J, Montana CG. 2007. Getting to the fat of the matter: models, methods and assumptions for dealing with lipids in stable isotope analyses. Oecologia 152:179-89.

Post DM. 2002. Using stable isotopes to estimate trophic position: models, methods, and assumptions. Ecology 83:703-18.

Prins HHT. 2000. Competition between wildlife and livestock in Africa. In: Prins HHT, Grootenhuis JG, Dolan TT, Eds. Wildlife conservation by sustainable use. Boston: Kluwer Academic Press. p 51-80.
Raburu PO, Masese FO. 2012. A fish-based index for assessing ecological integrity of riverine ecosystems in Lake Victoria Basin. River Res Appl 28:23-38.

Rasmussen JB, Trudeau V, Morinville GR. 2009. Estimating the scale of fish feeding movements in rivers using $\delta^{13} \mathrm{C}$ signature gradients. J Anim Ecol 78:674-85.

Rasmussen JB. 2010. Estimating terrestrial contribution to stream invertebrates and periphyton using a gradient-based mixing model for $\delta 13 \mathrm{C}$. J Anim Ecol 79:393-402.

Rau G. 1978. Carbon-13 depletion in a subalpine lake: carbon flow implications. Science 201:901-2.

Roach KA. 2013. Environmental factors affecting incorporation of terrestrial material into large river food webs. Freshw Sci 32:283-98.

Smart JS. 1972. Quantitative characterization of channel network structure. Water Resour Res 8:1487-96.

Subalusky AL, Dutton CL, Rosi-Marshall EJ, Post DM. 2014. The hippopotamus conveyor belt: vectors of carbon and nutrients from terrestrial grasslands to aquatic systems in sub-Saharan Africa. Freshw Biol. doi:10.1111/fwb.12474.

Tamooh F, Borges AV, Meysman FJR, Van Den Meersche K, Dehairs F, Merckx R, Bouillon S. 2013. Dynamics of dissolved inorganic carbon and aquatic metabolism in the Tana River Basin, Kenya. Biogeosciences 10:6911-28.

Tank JL, Rosi-Marshall EJ, Griffiths NA, Entrekin SA, Stephen ML. 2010. A review of allochthonous organic matter dynamics and metabolism in streams. J N Am Benthol Soc 29:1 18-46.

Thorp JH, Delong MD. 1994. The riverine productivity model: an heuristic view of carbon sources and organic processing in large river ecosystems. Oikos 70:305-8.

Vannote RL, Minshall GW, Cummins KW, Sedell JR, Cushing CE. 1980. The river continuum concept. Can J Fish Aquat Sci 37:130-7.

Wardle DA, Bardgett RD, Callaway RM, Van der Putten WH. 2011. Terrestrial ecosystem responses to species gains and losses. Science 332:1273-7.

Weidel BC, Carpenter SR, Kitchell JF, Vander Zanden MJ. 2011. Rates and components of carbon turnover in fish muscle: insights from bioenergetics models and a whole-lake 13C addition. Can J Fish Aquat Sci 68:387-99.

Zeug SC, Winemiller KO. 2008. Evidence supporting the importance of terrestrial carbon in a large-river food web. Ecology 89:1733-43.

Zimov SA. 2005. Pleistocene park: return of the mammoth's ecosystem. Science 308:796-8. 